\title{
Small-Scale Ion Exchange Removal of Cesium and Technetium from Hanford Tank 241-AN-102
}

by

N. M. Hassan

Westinghouse Savannah River Company

Savannah River Site

Aiken, South Carolina 29808

R. Hayden (Contact)

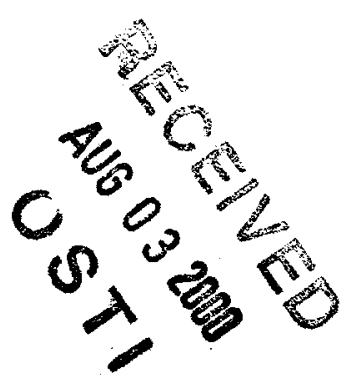

W. D. King

D. J. McCabe

M. L. Crowder

This paper was prepared in connection with work done under the above contract number with the U.S. Department of Energy. By acceptance of this paper, the publisher and/or recipient acknowledges the U.S.

Government's right to retain a nonexclusive, royalty-free license in and to any copyright covering this paper, along with the right to reproduce and to authorize others to reproduce all or part of the copyrighted paper. 


\section{DISCLAIMER}

This report was prepared as an account of work sponsored by an agency of the United States Government. Neither the United States Government nor any agency thereof, nor any of their employees, makes any warranty, express or implied, or assumes any legal liability or responsibility for the accuracy, completeness, or usefulness of any information, apparatus, product or process disclosed, or represents that its use would not infringe privately owned rights. Reference herein to any specific commercial product, process or service by trade name, trademark, manufacturer, or otherwise does not necessarily constitute or imply its endorsement, recommendation, or favoring by the United States Government or any agency thereof. The views and opinions of authors expressed herein do not necessarily state or reflect those of the United States Government or any agency thereof.

This report has been reproduced directly from the best available copy.

Available for sale to the public, in paper, from: U.S. Department of Commerce, National Technical Information Service, 5285 Port Royal Road, Springfield, VA 22161, phone: (800) 553-6847, fax: (703) $605-6900$

email: orders@ntis.fedworld.gov online ordering: http://www.ntis.gov/ordering.htm

Available electronically at http://www.doe.gov/bridge Available for a processing fee to U.S. Department of Energy and its contractors, in paper, from: U.S. Department of Energy, Office of Scientific and Technical Information, P.O. Box 62, Oak Ridge, TN 37831-0062, phone: (865)576-8401, fax: (865) $576-5728$ email: reportsladonis.osti.gov 


\section{DISCLAIMER}

Portions of this document may be illegible in electronic image products. Images are produced from the best available original document. 


\section{SMALL-SCALE ION EXCHANGE REMOVAL OF CESIUM AND TECHNETIUM FROM HANFORD TANK 241-AN-102}

$\operatorname{March} 29,2000$
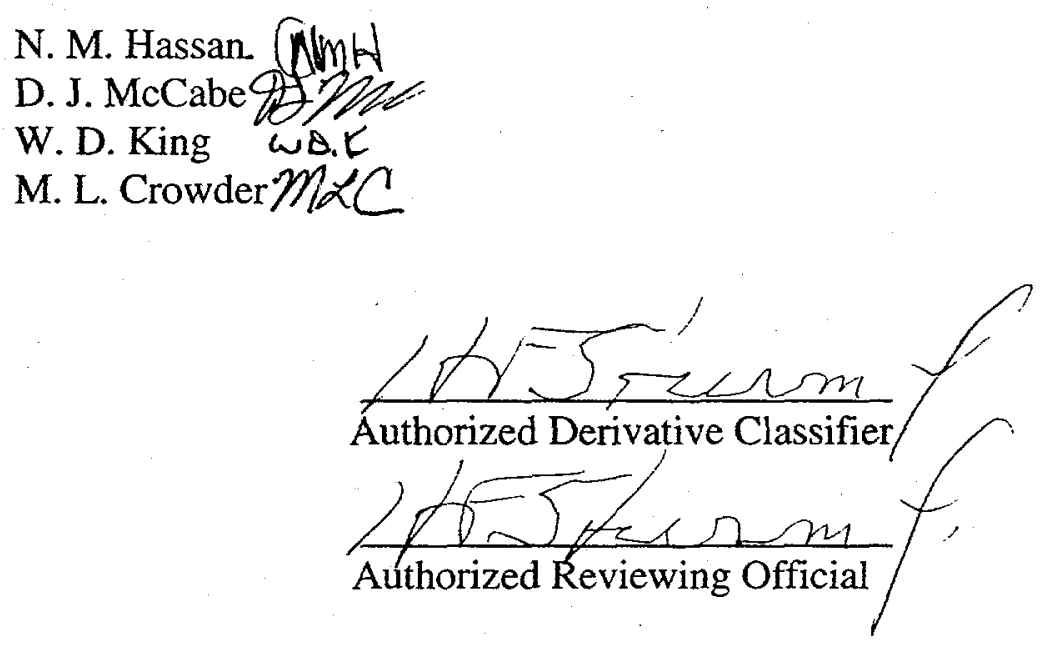

\section{DISCLAIMER NOTICE}

This report was prepared by Westinghouse Savannah River Company, Inc. (WSRC) on behalf of the U.S. Department of Energy (DOE), as an account of work sponsored by BNFL, Inc. Neither WSRC, DOE, the U.S. Government, or any person acting on their behalf makes any warranty, express or implied, or assumes any legal liability or responsibility for the accuracy, completeness, or usefulness of any information, apparatus, product, or process disclosed, or represents that its use would not infringe privately owned rights. Reference herein to any specific commercial product, process, or service by trade name, trademark, manufacturer, or otherwise, does not necessarily constitute or imply its endorsement, recommendation, or favoring by WSRC, DOE, or the U.S. Government. The views and opinions of authors expressed herein do not necessarily state or reflect those of WSRC, DOE, or the U.S. Government.

Savannah River Technology Center

Westinghouse Savannah River Company

Aiken, SC 29808 
Table of Contents

ii

List of Tables iii

List of Figures $\quad \cdot$ iv

SUMMARY V

1.0 INTRODUCTION 1

2.0 EXPERIMENTAL 2

2.1. Materials 2

2.2 Equipment 3

2.3 Procedure 4

2.3.1 Batch Contact 4

2.3.2 Cesium Column operation $\quad 5$

2.3.3 Technetium Column operation 6

3.0 RESULTS AND DISCUSSION 8

3.1 Batch Distribution Coefficients 8

3.2 Cesium Column Loading 10

3.3 Cesium Column Elution 11

\begin{tabular}{ll}
3.4 & Technetium Column Loading \\
\hline
\end{tabular}

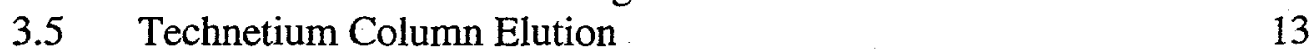

$\begin{array}{ll}3.6 & \text { Product Characterization } \\ 3.7 & 13\end{array}$

3.7 Spent Resin Digestion and Analysis 14

$\begin{array}{lll}4.0 & \text { CONCLUSION } & 15\end{array}$

$\begin{array}{lll}5.0 & \text { APPROVALS } & 16\end{array}$

$\begin{array}{lll}\text { 6.0 REFERENCES } & 17\end{array}$ 


\section{LIST OF TABLES}

Table 1. Envelope C (AN-102) Filtrate characterization Data 18

Table 2. $\quad$ Physical Property of SuperLig ${ }^{\circledR} 644$ and 639 resin $\quad 19$

Table 3. Sieve Analysis of SuperLig ${ }^{\circledR} 639$ Resin batch \#981015DHC-720011

Table 4. Sieve Analysis of SuperLig ${ }^{\circledR} 644$ Resin batch \# 981020mb48-563

Table 5. Batch Distribution Coefficients for Cs-137 SuperLig ${ }^{\circledR} 644$ Resin 20

Table 6. Batch Distribution Coefficients for Tc-99 SuperLig ${ }^{\circledR} 639$ Resin 21

Table 7. Cesium Ion Exchange Column loading Profiles 21

Table 8. Cesium Elution Profile for Lead Column 22

Table 9. Technetium Concentration Profiles for Envelope C on SuperLig ${ }^{\circledR} 639$ (Analysis by ICP-MS) 22

Table 10. Technetium Elution Profile (Lead Column) 23

Table 11. Characterization Data for Envelope C Decontaminated Product 24

Table 12. Characterization Data for Cs-137 Eluate Product 25

Table 13. Characterization Data for Tc-99 Eluate Product . $\quad 26$

Table 14. Resin Digestion and Analysis $\quad 27$ 


\section{LIST OF FIGURES}

Figure 1. Log-Log plot of cesium equilibrium distribution coefficient

Figure 2. Batch distribution coefficients and uptake for Cs on SuperLig ${ }^{\circledR} 644 \quad 28$

Figure 3. The loading breakthrough profile for Cs-137 on SuperLig ${ }^{\circledR} 644$ resin 29

Figure 4. $\mathrm{Na}^{+}$and free $\mathrm{OH}^{-}$concentrations in feed displacement and rinse solutions after Cs-137 ion exchange column loading

Figure 5. The eluate concentration profile for Cs-137 on SuperLig ${ }^{\circledR} 644$ resin 30

Figure 6. The loading breakthrough profile for Tc-99 on SuperLig ${ }^{\circledR} 639$ resin 30

Figure 7. Feed displacement and rinse plots of $\mathrm{Na}^{+}$and free $\mathrm{OH}^{-}$after Tc-99 ion exchange column loading

Figure 8. The eluate concentration profile for Tc-99 on Superlig ${ }^{\circledR} 639$ resin 


\section{SUMMARY}

To demonstrate the flow-sheet parameters of the Hanford River Protection Project facility being designed by BNFL, Inc., a sample of Envelope C salt solution was decontaminated for cesium and technetium by ion exchange. The sample, a supernate from Hanford Tank AN-102, had previously been subjected to entrained solids removal and $\mathrm{Sr} / \mathrm{TRU}$ precipitation and filtration processes before the ion exchange process was performed. Radioactive cesium and technetium removal was accomplished with two sets of ion exchange columns. Each set was connected as a series of two columns in lead-lag configuration. The cesium and technetium removal columns were previously used for decontamination of Envelope A (Hanford Tank AN-103) salt solution and stored thereafter for two months in de-ionized water. The ion exchange process steps for decontamination of Envelope $C$ were the same as previously described ${ }^{\prime}$ and briefly include: 1) resin preconditioning, 2) loading cycle, 3) caustic wash and water rinsing, 4) elution, and 5) resin regeneration. To determine the number of column volumes of feed sample to process, batch distribution coefficients $\left(\mathrm{K}_{d}\right)$ and wet resin density of the ion exchange resins were measured. The $K_{d}$ values were determined over a wide range of cesium and technetium equilibrium concentrations in order to generate equilibrium isotherms. The isotherm data were fitted to a Freundlich-Langmuir Hybrid equation to determine parameters needed for successful modeling of the breakthrough behavior. The modeling results were used to aid in scale up of the design of the ion exchange columns. The decontaminated sample product was used in demonstration of the Low Activity Waste vitrification process, and concentrated cesium and technetium eluate products were blended with other sample streams for High Activity Waste vitrification demonstration.

The cesium distribution coefficient (mean $\mathrm{K}_{d}$ value) for SuperLig ${ }^{\circledR} 644$ resin with Envelope C (Tank AN-102) was $759 \mathrm{~mL} / \mathrm{g}$. Based on resin density of $0.4 \mathrm{~g} / \mathrm{mL}$, the estimated number of column volumes to process at $50 \%$ breakthrough ("lambda value") was $\sim 304$. Prior work ${ }^{2}$ indicated that the $50 \%$ breakthrough would normally be reached at $37 \%$ of this value (i.e. 112 column volumes). To obtain an equilibrium isotherm over a wide range of cesium concentrations, small volumes of Envelope $C$ samples were twice re-contacted with fresh resin and additional $\mathrm{K}_{\mathrm{d}}$ values were determined at ambient cell temperature $\left(26 \pm 1^{\circ} \mathrm{C}\right)$. Also, a primary and duplicate sample were spiked with nonradioactive cesium to obtain $\mathrm{K}_{d}$ values at higher initial concentrations. It was determined that the batch distribution coefficients generally decrease with increasing cesium concentration. As expected, the $\mathrm{K}_{d}$ values decreased at the higher end of the cesium concentration range studied.

The performance of the cesium ion exchange columns exceeded the pretreatment flow-sheet design criteria. Only $11 \%$ breakthrough of cesium was observed after processing 85 column volumes through the lead column. The lag column removed the remaining cesium to achieve an overall decontamination of $99.93 \pm 0.03 \%(\mathrm{DF}=1790)$ The elution of cesium from the loaded column with $0.5 \mathrm{M} \mathrm{HNO}_{3}$ was effective. The elution data indicated $78 \%$ removal of adsorbed cesium within the first 5 column 
volumes and a $99.8 \%$ removal of elutable cesium after 19 column volumes. Only trace cesium remains on the resin after elution.

The technetium distribution coefficient (mean $\mathrm{K}_{d}$ value) for SuperLig ${ }^{\circledR} 639$ was $15.5 \mathrm{~mL} / \mathrm{g}$. However, the resin is not expected to remove technetium that is not present as the pertechnetate ion, and this sample contained $77 \%$ as non-pertechnetate. The mean $\mathrm{K}_{\mathrm{d}}$ value calculated for the pertechnetate ion species was $142 \mathrm{~mL} / \mathrm{g}$. The estimated number of column volumes to process at $50 \%$ breakthrough (lambda value) for the extractable pertechnetate fraction was 67 column volumes. Our repeated contact experiments show that only $22.5 \%$ of the technetium in Envelope C (AN-102) is pertechnetate ion and could readily be extracted by SuperLig ${ }^{\circledR} 639$ resin. The equilibrium reaction between pertechnetate and other form(s) of technetium in Hanford wastes is not known. Therefore, it is not known if the repeated batch contacts altered the ratio between pertechnetate and other form(s) of technetium present in the AN-102 sample. Similarly, it is not known if the Sr/TRU removal process, which was done prior to the batch and column tests after different storage duration, altered the ratio of ionic states of technetium.

The technetium column loading on SuperLig ${ }^{\circledR} 639$ showed an immediate breakthrough. This was expected since Envelope C sample contains a relatively large fraction of technetium that is not present as the pertechnetate (anion) species and therefore could not be extracted by SuperLig ${ }^{\circledR} 639$ resin. The percent removal of technetium from Envelope C (AN-102) salt solution was $45.74 \pm 2.08 \%$, which is higher than the expected maximum $22.5 \%$. The cause of the better-than-expected removal of technetium has not been identified. Elution of technetium from the resin with de-ionized water at $1 \mathrm{CV} / \mathrm{h}$ was efficient with over $97 \%$ of the removable technetium eluted within the first 10 column volumes. Since the concentration of technetium in the eluate could not be monitored online, elution was continued for additional 30 column volumes to ensure less than $1 \%$ of the initial concentration of technetium is eluting from the resin. Although this long elution was not originally expected, the extended elution period should not affect the overall waste processing time cycle, since the loading cycle is also longer than projected. Several proposals are considered to improve the elution process.

Characterization results show that the cesium and technetium content in the final decontaminated product were $2.03 \mathrm{E}-05 \mathrm{Ci} / \mathrm{mole} \mathrm{Na}$ and $8.29 \mathrm{E}-06 \mathrm{Ci} / \mathrm{mole} \mathrm{Na}$, respectively. BNFL Inc. plans to vitrify the AN-102 waste, achieving a sodium oxide incorporation of $11.8 \mathrm{wt} \%$ in the immobilized low-activity waste (ILAW) form. For this hypothetical glass, the concentration of Cs-137 and Tc-99 are estimated to be $0.2 \mathrm{Ci} / \mathrm{m}^{3}$ and $0.082 \mathrm{Ci} / \mathrm{m}^{3}$, respectively. Per US DOE contract specification (2.2.2.8), the average concentrations of ${ }^{137} \mathrm{Cesium}\left({ }^{137} \mathrm{Cs}\right),{ }^{90}$ Strontium $\left({ }^{90} \mathrm{Sr}\right)$, and ${ }^{99}$ Technetium $\left({ }^{99} \mathrm{Tc}\right)$ are limited to less than 3,20 , and $0.1 \mathrm{Ci} / \mathrm{m}^{3}$, respectively. ${ }^{6}$ The average concentrations are calculated by summing the actual inventories of each of the above radionuclides in waste packages and dividing by the total volume of waste in these packages. Thus, a minimum of $25 \%$ to $30 \%$ removal of the ${ }^{99} \mathrm{Tc}$ present in the feed from AN-102 was required. The radionuclide contents of $\mathrm{Cs}$ and $\mathrm{Tc}$ in decontaminated Envelope $\mathrm{C}$ product sample are respectively 0.106 and $0.043 \mu \mathrm{Ci} / \mathrm{mL}$ as shown in Table 11 . The chemical compositions 
in the final decontaminated product and eluate concentrates were as expected with the exception of uranium and TOC, which were concentrated by the cesium ion exchange resin and chloride ions which were concentrated by the technetium resin. 


\subsection{INTRODUCTION}

The pretreatment process for BNFL, Inc.'s Hanford River Protection Project is to provide decontaminated low activity waste and concentrated eluate streams for vitrification into low and high activity waste glass, respectively. The pretreatment includes sludge washing, filtration, precipitation, and ion exchange processes to remove entrained solids, cesium, transuranics, technetium, and strontium. The cesium (Cs-137) and technetium (Tc-99) ion exchange removal is accomplished by using SuperLig ${ }^{\mathbb{B}} 644$, and 639 resins from IBC Advanced Technologies, American Fork, Utah. The resins were shown to selectively remove cesium and technetium (as anionic pertechnetate ) from alkaline salt solutions. The efficiency of ion exchange column loading and elution is a complex function involving feed compositions, equilibrium and kinetic behavior of ion exchange resins, diffusion, and the ionic strength and $\mathrm{pH}$ of the aqueous solution. A previous experimental program completed at the Savannah River Technology Center ${ }^{2}$ demonstrated the conceptualized flow sheet parameters with an Envelope C sample from Hanford Tank 241-AN-107. Those experiments also included determination of Cs and Tc batch distribution coefficients by SuperLig ${ }^{\circledR} 644$ and 639 resins and demonstration of small-scale column breakthrough and elution. The experimental findings were used in support of preliminary design bases and pretreatment flow sheet development by BNFL, Inc.

The objectives of this ion exchange study are the following:

(1) Determine the batch distribution coefficients ( $\mathrm{K}_{\mathrm{d}}$ values) and percent removal for cesium (Cs-137) and technetium (Tc-99) ions on SuperLig ${ }^{\circledR}$ ion exchange materials (SuperLig ${ }^{\circledR} 644$ and 639) with Envelope C from Hanford Tank AN-102 salt solution.

(2) Provide equilibrium isotherm data to determine the parameters for successful modeling of the ion exchange column breakthrough and elution performance.

(3) Demonstrate Cs-137 and Tc-99 loading and elution profiles for Envelope C using SuperLig ${ }^{\circledR} 644$ and 639 ion exchange resins.

(4) Provide decontaminated (pretreated) product samples for vitrification into low activity waste glass and concentrated eluate product samples for vitrification into high activity waste glass.

(5) Provide information on the composition of caustic displacement and water wash solutions used between loading, elution, and regeneration cycles.

The batch contact experiments were performed to determine the equilibrium distribution coefficients ( $\mathrm{K}_{d}$ values) and percent removal for cesium and technetium ions. The $\mathrm{K}_{d}$ values represent a measure of the equilibrium distribution between the aqueous phase and the ion exchanger at a specific solid to liquid ratio. Also the $K_{d}$ values provide 
valuable information on selectivity, capacity, and affinity of an ion exchange material to remove ions from complex aqueous solutions. Specific tests are performed by the addition of a small quantity of ion exchange material into a small volume of salt solution containing a known exchangeable ion(s).

The factors that effect the $\mathrm{K}_{\mathrm{d}}$ values and percent removal of the ion(s) include the temperature, initial concentration of the ions in solution, and the solid/liquid ratio during the contact. Duration of the contact must be sufficient to achieve equilibrium or a constant comparative value must be used. The loading capacity for the ion exchange columns is determined from batch $\mathrm{K}_{d}$ experiments conducted at the same conditions as those of the columns. The $K_{d}$ values are also determined at different equilibrium concentrations to establish a robust ion exchange decontamination process across the broad range of cesium and technetium concentrations that will be encountered as the solution passes through the columns. These data will be used as input to a computer model to determine the scale-up parameters. The computer modeling work will be reported in a future document.

The small ion exchange column experiments were performed in the Intermediate Level Cells at Savannah River Technology Section, allowing remote handling of materials. The experiments were conducted at ambient temperature $\left(26 \pm 1^{\circ} \mathrm{C}\right)$ using two sets of cesium and technetium ion exchange columns. Each set consisted of two columns connected in series, one as the lead column and the other as the lag column. The cesium columns were each packed with $6.2 \mathrm{~mL}$ of SuperLig ${ }^{\circledR} 644$ and the technetium columns each contained $5.6 \mathrm{~mL}$ of SuperLig ${ }^{\circledR} 639$ resin. The feed samples were allowed to pass downflow through the lead column and collected from the lag column in small fractions. The lead and lag columns were periodically sampled during the column loading to detect early breakthrough and ensure that the effluent concentration does not exceed $50 \%$ of the influent concentration. Once the analytical results were received and confirmed to meet the LAW acceptance criteria, the fractions were combined and further characterized to verify that the effluent met the vitrification process acceptance criteria.

\subsection{EXPERIMENTAL}

\subsection{Materials}

Envelope C (Hanford Tank 241-AN-102) salt solution was used for determination of batch distribution coefficients and column breakthrough performance tests. The solution received from Hanford was subjected to entrained solids removal and Sr/TRU precipitation filtration processes reported elsewhere. ${ }^{5}$ The sample was diluted during $\mathrm{Sr} / \mathrm{TRU}$ precipitation filtration processes to $\sim 6 \mathrm{M}\left[\mathrm{Na}^{+}\right]$. After dilution, the filtrate had a measured density of $1.234 \mathrm{~g} / \mathrm{mL}$ and initial Cs-137 and Tc-99 concentrations of 190 $\mu \mathrm{Ci} / \mathrm{mL}$ and $0.079 \mu \mathrm{Ci} / \mathrm{mL}$, respectively. The diluted sample was used as received for batch distribution coefficient ( $\mathrm{K}_{d}$ values) and column performance tests. Table 1 shows the chemical and radionuclide compositions of Envelope $\mathrm{C}$ samples from Hanford Tank AN-102 and Tank AN-107. The latter sample was previously tested at Savannah River 
Technology Center for cesium and technetium removal with SuperLig ${ }^{\circledR}$ resins. ${ }^{2}$ The characterization data for the two samples from Hanford Tanks AN-102 and AN-107 appear to be similar, with the exception of the free hydroxide ion concentration in Tank AN-102, which is $\sim 4$ times higher than that in Tank AN-107. However, the free hydroxide content of the AN-107 sample shown in Table 1 includes buffering by the organic salts, and the true value of hydroxide ion concentration is much lower. Prior to ion exchange testing with the AN-107 sample, the free hydroxide concentration was increased by $0.3 \mathrm{M}$ by addition of sodium hydroxide solution. Similar to previous work, the chemical reagents used in the $\mathrm{AN}-102$ tests for resin pretreatment and column elution were sodium hydroxide and nitric acid solutions, respectively. These reagents were prepared from ACS certified reagents from Fisher Scientific, Inc.

The ion exchange materials used for cesium and technetium removal from Envelope C sample were SuperLig ${ }^{\circledR} 644$ (batch \# 981020MB48-563) and 639 (batch \# 981015 DHC720011), respectively. SuperLig ${ }^{\circledR} 644$ is a polymerized proprietary organic material supplied as 20-70 mesh granules. SuperLig ${ }^{\circledR} 639$ is composed of polystyrene beads with an attached proprietary organic compound. IBC Advanced Technologies, American Fort, Utah, supplied the resin for testing. The physical properties of the SuperLig ${ }^{\circledR} 644$ and 639 batches used in this study were measured and the results are presented in Table 2. The F-factor values shown in the last column (Table 2) were obtained by drying a sub-sample of the resin over night in a vacuum oven at $105^{\circ} \mathrm{C}$. The sieve analyses for SuperLig ${ }^{\circledR} 644$ and 639 resin particles are presented in Tables 3 and 4, and have been previously reported. ${ }^{4}$

\subsection{Equipment}

The equipment used for the ion exchange column tests was assembled remotely in the shielded Intermediate Level Cells in a laboratory module at the Savannah River Technology Center. Each column had been previously used for the Envelope A sample processing, and were reused after being filled with deionized water and storing for $\sim 2$ months. For each experiment, two columns (SuperLig ${ }^{\circledR} 644$ or 639) were connected in series, with a sampling port between. The columns were made of a medium wall Pyrex glass tubing with an inside diameter of $11 \mathrm{~mm}$ and a total length of $30 \mathrm{~cm}$. A plastic coating was applied to the outside walls of the columns to contain shattered glass in case of a rupture. A 200 mesh stainless steel screen was fitted into bottom of each column. Column top assemblies included a fill reservoir, a pressure gauge, a pressure relief valve, and feed inlet ports. The fill reservoir on column top assemblies also served as a vent to permit draining liquid, if necessary. The top assemblies were connected to the glass columns by glass ground joints and tightly fitted screw caps. A ruler affixed to the column wall was used to allow observation of resin bed height changes and liquid level. All tubing connections were made of transparent polyethylene lines that had quickconnect fittings attached to each end; the lines had an inside diameter of 0.125-inch. 
The equipment used for batch contact tests consists of $30-\mathrm{mL}$ polyethylene bottles, a Mix-Max ${ }^{\circledR}$ orbital shaker, nylon filter units $(0.45 \mu \mathrm{m})$, plastic filter holders, and an analytical balance accurate to $\pm 0.001 \mathrm{~g}$. A house-supplied vacuum and a trap assembly were used during sample filtration. All experiments were performed in the shielded Intermediate Level Cell, allowing remote handling of materials.

\subsection{Procedure}

\subsubsection{Batch contact}

All batch contact experiments were conducted in duplicate and at cell ambient temperature of $26 \pm 1^{\circ} \mathrm{C}$. A standard batch contact test, followed by two sequential recontacts of the filtrates with fresh resin and an independent cesium spiked batch test were conducted in the shielded cell. The technetium and cesium tests each used the same batch of "as received resin".

In the "standard" cesium and technetium batch tests, a known volume of salt solution $(\sim 18 \mathrm{~mL})$ was added into polyethylene bottle with a known quantity of ion exchange resin $(\sim 0.18 \mathrm{~g})$. The phase ratio, solution-to-resin, was $\sim 100: 1$ for most of the experiments. The bottles containing the solution and the resin were placed on the orbital shaker and gently shaken for $24 \pm 1$ hours at cell ambient temperature $\left(26 \pm 1^{\circ} \mathrm{C}\right)$. Control samples $(\sim 18 \mathrm{~mL}$ of salt solution) were treated in the same way as those of duplicate test samples without the addition of the resin. The concentrations of Cs-137 and Tc-99 in control samples were used as the starting initial concentrations to determine the $\mathrm{K}_{\mathfrak{d}}$ values and percent removed by the resin. The ambient cell temperature was recorded at the beginning and end of each test. After the contact period, the resin was separated from the sample solution by filtration through individual 0.45 -micron nylon filter unit. A $1-\mathrm{mL}$ subsample of the filtrate was removed from the cell and analyzed by the Analytical Development Section of the Savannah River Technology Center. Sub-samples were often diluted (10:1) with de-ionized water to reduce the radiation dose rate before the samples are transferred from hot cell to analytical laboratories. All dilutions and measurements were performed based on mass and corrected for density of the solution to ensure accuracy. Concentration of the ion(s) in solution is determined by radioactive counting (Cs-137) or inductively coupled plasma-mass spectroscopy (technetium at mass 99) before and after contact with the resin; the quantity of the ion(s) on the exchanger is determined by difference. No correction for any ruthenium isotope was needed, based on the distribution of masses 100-104. Results were corrected for dilution, where appropriate.

Following the "standard" batch test, two sequential re-contact tests were performed on filtrates. In the first re-contact test, a known volume $(\sim 12 \mathrm{~mL})$ of the filtrate that had been separated from the resin in the standard test was re-contacted with fresh ion exchange resin $(\sim 0.12 \mathrm{~g})$. The fresh resin and the filtrate were gently shaken for $24 \pm 1$ hours. After equilibration, the resin was separated from the solution by filtration under vacuum with a 0.45 -micron nylon filter unit. A $1-\mathrm{mL}$ sub-sample of the first re-contact filtrate was 
removed from cell and submitted for analysis by the radioactive counting technique for Cs137 or Inductively Coupled Plasma-Mass Spectroscopy (ICP-MS) for Tc-99. The second re-contact was conducted by gently shaking a known volume $(\sim 10 \mathrm{~mL})$ of the first recontact filtrate with fresh ion exchange resin $(\sim 0.1 \mathrm{~g})$ for $24 \pm 1$ hours. After equilibration, the resin was separated from the solution by filtration under vacuum with 0.45 -micron nylon filter unit. A $1-\mathrm{mL}$ sub-sample of the second re-contact filtrate was submitted for analysis.

Following the two sequential batch contact tests, small quantities of cesium nitrate (in water) were spiked into a known volume of the original Envelope $\mathrm{C}$ salt solution. This was done to increase the initial concentration of $\mathrm{Cs}$ in test solutions by a factor of $\sim 10$. Because of the size of the spike sample and the density difference of the spike and the test solution, it was necessary to add the test solution into a polyethylene bottle containing the spike. The spiked solution was then shaken manually in the cell to get good mixing before contacting with the resin. The spiked test solution $(\sim 10 \mathrm{~mL})$ was gently shaken with fresh ion exchange resin $(\sim 0.1 \mathrm{~g})$ for $24 \pm 1$ hours. A control spike sample was also treated in identical steps as the duplicate test samples. After the contact period, the solution was separated from the resin by filtration under vacuum using $0.45-\mu \mathrm{m}$ nylon filter. A $1-\mathrm{mL}$ sub-sample of the filtrate (spiked solutions) was removed from the shielded cell and analyzed for total cesium by inductively coupled plasma -mass spectroscopy (ICP-MS). Radioactive counting technique was employed for measurement of Cs-137 content in the samples.

\subsubsection{Cesium column operation}

The cesium ion exchange columns were previously packed and pretreated in a chemical hood and subsequently used for the $\mathrm{AN}-103$ sample test. The pretreatment of the "as received" SuperLig ${ }^{\circledR} 644$ resin had been conducted according to the protocol developed by Savannah River Technology Center. ${ }^{4}$ This protocol, necessary for new or stored resin, included an acid-caustic cycle that resulted in a fully swollen resin bed in the sodium hydroxide form. After pretreatment, the volumes of the resin in the lead and lag columns were each approximately $6.4 \mathrm{~mL}$.

The pretreatment procedure designated for used of columns that had been stored for more than two weeks storage of the SuperLig ${ }^{\circledR} 644$ resin in de-ionized water include the following:

1. Pump 3 column volumes (CV) of $0.5 \mathrm{M} \mathrm{HNO}_{3}$ in 1 hour

2. Pump $3 \mathrm{CV}$ of de-ionized water in 1 hour

3. Pump $6 \mathrm{CV}$ of $0.25 \mathrm{M} \mathrm{NaOH}$ in 1 hour .

4. Initiate the test by pumping feed at $3 \mathrm{CV} / \mathrm{h}$ to the ion exchange columns

Two months after the cesium ion exchange column run with Envelope A (Tank AN103) salt solution, the columns were pretreated according to above procedure. On the day of the run, $6 \mathrm{CV}$ of $0.25 \mathrm{M}$ sodium hydroxide solution was pumped down flow through the 
lead into the lag column at $3 \mathrm{CV} / \mathrm{h}$. After this pre-conditioning, the feed was introduced into the lead column at $3 \mathrm{CV} / \mathrm{h}$ at ambient cell temperature $\left(26 \pm 1^{\circ} \mathrm{C}\right)$. The effluent was collected in 20 column volume fractions from the lag column. The first two $\mathrm{CV}$ of effluent were discarded to prevent dilution of the effluent by residual sodium hydroxide solution. Sub-samples were collected from the lead column after 5 and 10 column volumes of feed had passed through the lead column using a three-way Teflon ${ }^{\circledR}$ valve to direct liquid into the sampling line. The line was flushed for 3 minutes before each 10-minute sample collection. Subsequent sub-samples were collected in 10 column volume intervals. The volume of flush and sample liquid taken from the lead column effluent reduced the total volume of liquid pumped into the lag column and caused episodes of zero flow in the lag column. The flow stops for 13 minutes approximately every 3.3 hours.

The effluent from the lag column was routed to $120-\mathrm{mL}$ polyethylene collection bottles located at the lag column exit. Approximately 20 column volumes of effluent were collected in each bottle. The weight of effluent fractions was measured using an analytical balance; the corresponding volume was determined, dividing the effluent weight by the density of the feed. Sub- samples $(\sim 3 \mathrm{~mL})$ were collected from lag column after 20 column volumes of effluent were collected. The samples were counted at-line with a gamma counter to monitor the progress of the column loading. The samples from the lead and lag columns were submitted without dilution to Analytical Development Section of Savannah River Technology Center for analysis by radioactive counting. The loading cycle was terminated when the sample feed was consumed.

After termination of the loading cycle, the liquid hold-up was drained from the columns until the liquid level was $2 \mathrm{~cm}$ above the resin. The columns were flushed with 2 TAV (total apparatus volume) of $0.1 \mathrm{M}$ sodium hydroxide, followed by $2 \mathrm{TAV}$ of deionized water at $3 \mathrm{CV} / \mathrm{h}$. The flush and rinse solutions were collected from the lag column in $1 \mathrm{CV}$ increments. After the wash and rinse cycle, the two columns were disconnected; the tubing to the lead column was filled with $0.5 \mathrm{M}$ nitric acid. The pump dial set was then adjusted to provide a flow of $1 \mathrm{CV} / \mathrm{h}$ through the lead column. Eluate fractions were collected in $2 \mathrm{CV}$ increments. Sub-samples $(\sim 1 \mathrm{~mL})$ were collected periodically into dilution bottles containing $10 \mathrm{ml}$ of de-ionized water and analyzed by radioactive counting. The column was eluted with 19 column volumes of $0.5 \mathrm{M} \mathrm{HNO}_{3}$, followed by 3 column volumes of de-ionized water. The resin was then stored in de-ionized water.

\subsubsection{Technetium column operation}

The technetium removal from Envelope C (Hanford Tank AN-102) salt solution was accomplished with a set of two ion exchange columns in series. The columns were previously employed for technetium removal from Envelope A (Hanford Tank AN103) salt solution. The wet volume of the resin in the columns was $\sim 5.6 \mathrm{~mL}$ and the resin bed height was $5.9 \mathrm{~cm}$ (i.e. an $\mathrm{L} / \mathrm{D}$ ratio of 6.2 ). The purpose of the lag column was to further decontaminate the feed sample in order achieve the low activity waste vitrification acceptance criteria. The resin was held in place with a small amount of quartz wool and 
glass beads. Previous testing with Envelope A had shown that a portion of the resin floats unless restrained.

On the day of the run, the resin was pre-conditioned with $3 \mathrm{CV}$ of $1 \mathrm{M} \mathrm{NaOH}$ in one hour. The feed to technetium ion exchange columns, which had been decontaminated for Cs, was pumped down-flow through the lead column at 3 column volumes per hour. The flow rate was adjusted during the early stages of the run to accommodate for the density change between the conditioning solution and the feed. The flow rate was periodically checked by weighing samples collected from the lag column for 10 minutes. Also, the weight of effluent fractions at 20 column volume intervals was measured and using the density of the effluent solutions, the flow rate was verified.

Sub-samples $(3 \mathrm{~mL})$ were collected from the lead column after 5 and 10 column volumes of feed were processed through the lead column. Subsequent subsamples were collected after each 10 column volumes. Sub-samples were collected through a three-way Teflon ${ }^{\circledR}$ valve at the lead column exit sampling line. The effluent from the lead column was routed to sample vials located under the sampling line. The line was flushed for 3 minutes, followed by 10-minute sample collection. Effluent sub-samples $(\sim 3 \mathrm{~mL})$ were submitted to Analytical Development Section of Savannah River Technology Center for analysis of Tc-99 mass by inductively coupled plasma-mass spectroscopy. When not in sampling mode, the effluent from the lead column was allowed to pass down flow into the lag column that served to further decontaminate the feed sample. Sampling the lead column resulted in a discontinuous flow rate for the lag column, where flow stops for 13 minutes approximately every 3.3 hours. The lag column effluent was collected in 20 column volume increments, then sampled for 10 minutes. Sub-samples $(\sim 1 \mathrm{~mL})$ from the lag column were submitted without dilution for analysis to Analytical Development Section of Savannah River Technology Center. The column loading was terminated when the available feed was consumed.

Upon completion of the technetium loading cycle, the feed hold up was drained from the columns until the liquid level was $2 \mathrm{~cm}$ above the surface of the glass beads. The columns were then washed in series with $2 \mathrm{TAV}$ (TAV = total apparatus volume; the volume of tubing and liquid headspace in the lead column) of $0.1 \mathrm{M}$ sodium hydroxide, followed by two TAV of de-ionized water. The wash and rinse effluent solutions were collected from the lag column in small increments of 2 column volumes each. Sub-samples $(\sim 1 \mathrm{~mL})$ were collected each time after one column volume of solution had passed through the lag column.

Upon completion of the column wash and rinse, the lead and lag columns were disconnected. The flow rate through the lead column was adjusted to $1 \mathrm{CV} / \mathrm{hr}$. The eluent (de-ionized water) was pumped at ambient temperature down flow into the lead column and collected in two column volume fractions. The elution was conducted at cell ambient temperature of $26 \pm 1^{\circ} \mathrm{C}$. Eluate fractions were collected into $30-\mathrm{mL}$ polyethylene bottles. The elution was continued until 40 column volumes of water had passed through the 
column. Sub-samples of the eluate were collected between fractions and were analyzed for Tc-99 by ICP-MS.

\subsection{RESULTS AND DISCUSSION}

3.1. Batch Distribution Coefficients: Batch contact experiments were performed to determine equilibrium distribution coefficients ( $K_{d}$ values) and percent removal for $\mathrm{Cs}-137$ and Tc-99. The batch experiments include the addition of a small quantity of ion exchange materials into a known volume of the salt solution containing known quantities of $\mathrm{Cs}$ and $\mathrm{Tc}$ ions. The concentration of $\mathrm{Cs}-137$ in solution was determined by radioactive counting before and after contact with the SuperLig ${ }^{\otimes} 644$ resin. The concentration of Tc- 99 before and after contact was determined by inductively coupled plasma-mass spectroscopy (ICP-MS). The quantity of the ions on the resins was determined by difference.

Batch distribution coefficients ( $K_{d}$ values) and percent removal were calculated from the following equations :

$$
K_{d}=\frac{\left(C_{i} / C_{f}-1\right) V}{(M . P)}
$$

and

$$
\% R=\frac{100\left(C_{i}-C_{f}\right)}{C_{i}}
$$

where $C_{i}$ is the initial concentration of salt solution, $C_{f}$ is the final (equilibrium) concentration, $V$ is the volume of liquid sample, $M$ is the "as received" mass of the resin, and $F$ is the mass of dried resin divided by the mass of "as received" resin (i.e., the dry weight correction or F-factor).

The $\mathrm{K}_{d}$ values and percent removals (\%R) for cesium are presented in Table 5. The values shown in last column (Table 5) represent the mean of duplicate samples. The percent relative standard deviations (\% RSD) for the standard batch contact, first and second re-contacts, and spiked batch test $K_{d}$ values were $4.07,0.7,1.19$, and $3.86 \%$, respectively. This indicates that duplication results were generally good. It is noted that the mean standard $K_{d}$ value for adsorption of Cs from Envelope $C$ on SuperLig ${ }^{\circ} 644$ resin was $759 \mathrm{~mL} / \mathrm{g}$. The mean $\mathrm{K}_{d}$ values for first and second re-contacts of prior filtrates with fresh ion exchange resin were 1380 and $1366 \mathrm{~mL} / \mathrm{g}$, respectively. Thus, decreasing the concentration of cesium had a significant effect on the $K_{d}$ values for SuperLig ${ }^{\otimes} 644$ resin, as expected. For example, the $K_{\alpha}$ s reduced from 1380 to $759 \mathrm{mg} / \mathrm{L}$ and from 759 to 302 $\mathrm{mg} / \mathrm{L}$ as the cesium concentration in the solution phase increased from 7.74E-06 to $6.33 \mathrm{E}-5$ $\mathrm{M}$ and from $6.33 \mathrm{E}-5$ to $1.0 \mathrm{E}-3 \mathrm{M}$, respectively. This may be clearly illustrated by plotting on a $\log -\log$ scale the $\mathrm{K}_{d}$ values as a function of $\mathrm{Na} / \mathrm{Cs}$ ratios as shown in Figure 1. It can 
be seen that the $K_{d}$ values increase logarithmically with increasing $\mathrm{Na} / \mathrm{Cs}$ ratio and the relationship may be represented by the following expression:

$$
\log \left(\mathrm{K}_{\mathrm{d}}\right)=\log (66.638)+0.17 \log [\mathrm{Na} / \mathrm{Cs}]
$$

It is worth noting that the data fit this logarithmic relation reasonably well with R-squared value of 0.911 . Equation (3) gives a quick and simple means for calculating approximate $\mathrm{K}_{\mathrm{d}}$ values for this solution. This expression is invalid for solutions containing different concentrations of potassium and free hydroxide, which have the greatest effect on the cesium $\mathrm{K}_{\mathrm{d}}$ values for SuperLig ${ }^{\circledR} 644$ resin. The measured $\mathrm{K}^{+}$and $\mathrm{OH}^{-}$concentrations of the AN-102 feed sample (that had been processed through Sr/TRU removal and filtration were 0.029 and $1.69 \mathrm{M}$, respectively.

The uptake of cesium by the SuperLig ${ }^{\circledR} 644$ resin was calculated from concentration of cesium on the resin, the volume of the solution, and the mass of the resin. Figure 2 shows a log-log plot of cesium uptake vs. equilibrium concentration for Envelope $\mathrm{C}(\mathrm{AN}-102)$ salt solution. Thus, a linearized Freundlich equation may be written as

$$
\log q=\log K+\frac{1}{n} \log C_{e}
$$

where $q$ is the cesium uptake per unit mass of resin, $\mathrm{C}_{e}$ is the cesium concentration in the solution phase at equilibrium, The empirical constants, $\mathrm{K}$ and $\mathrm{n}$ can be determined by a regression package. It can be seen that the equilibrium data for cesium on SuperLig ${ }^{\circledR} 644$ are very well represented $\left(\mathrm{R}^{2}=0.996\right)$ by the Freundlich expression

$$
q=84.252 C_{e}^{0.83}
$$

A detailed analysis of the data correlation and column modeling will be reported in a separate document.

The loading of cesium on SuperLig ${ }^{\circledR} 644$ up to $50 \%$ breakthrough was estimated from the mean standard $K_{d}$ value and the wet density ${ }^{1}$ of the resin. The Lambda $(\lambda)$ value for Envelope C (AN-102) loading on the resin was calculated as

$$
\lambda=\mathrm{K}_{\mathrm{d}} \times \rho=759 \mathrm{~mL} / \mathrm{g} \times 0.4 \mathrm{~g} / \mathrm{mL}=303
$$

Thus, the estimated column volumes of feed sample that can be processed before a $50 \%$ breakthrough occurs was 303 . Previous work ${ }^{2}$ with an Envelope $\mathrm{C}$ sample, however, indicated that the breakthrough would occur at $37 \%$ of this value. Therefore, the adjusted lambda value for Envelope $\mathrm{C}$ was 112 column volumes. 
Table 6 shows the mean $K_{d}$ values and percent removals for SuperLig ${ }^{\circledR} 639$ resin. This resin will extract only the pertechnetate form of technetium. It can be seen that the mean standard $\mathrm{K}_{\mathrm{d}}$ value for total Tc-99 was $15.5 \mathrm{~mL} \mathrm{~g}$. It is evident from these results that as the exchangeable pertechnetate species in solution depletes, the amount adsorbed onto the resin decreases. While $87 \%$ of the extractable technetium (pertechnetate) was removed during the standard batch contact, the first re-contact appears to have removed the remaining amount. Thus, after the first recontact, $\sim 3550 \mu \mathrm{g} / \mathrm{L}$ of the technetium remained in solution. Since this amount is indistinguishable from that after the second recontact, a second "pertechnetate only" $K_{d}$ cannot be accurately calculated. The results indicate that a maximum of $1032 \mu \mathrm{g} / \mathrm{L}$ or $22.5 \%$ of the total Tc present in Envelope C salt solution was pertechnetate (anion) species. Using this value as the total pertechnetate concentration, the corresponding standard $\mathrm{K}_{\mathrm{d}}$ value for the "pertechnetate-only" ion species is $142 \mathrm{~mL} \mathrm{~g}$. This assumes that sequential batch contacts do not affect the ratio of pertechnetate to nonpertechnetate. Other factors, such as the presence of Ru-99 masking the Tc-99 analysis are unlikely interferences due to the absence of masses 100-104 amu. Another possibility is that the technetium is all present as pertechnetate, but an unknown chelant prevents adsorption onto the resin. This explanation is also extremely unlikely, as the resin is a very strong absorbent for pertechnetate. If another chelant interfered, it would have to form such a strong bond that $<10 \%$ of it partitions to the resin. It is possible that the $\mathrm{Sr} / \mathrm{TRU}$ precipitation process impacted the ratio of pertechnetate to non-pertechnetate, since a powerful oxidant (sodium permanganate) is added to the solution. The batch contacts were performed 4 weeks after the Sr/TRU removal and the column tests were performed 6 .weeks after the removal.

The pertechnetate loading capacity at $50 \%$ breakthrough was estimated from the batch distribution coefficient and the wet density of the SuperLig ${ }^{\circledR} 639$ resin. The estimated column volume to process at $50 \%$ breakthrough or the Lambda $(\lambda)$ was

$$
\lambda=K_{d} \times \rho=142 \mathrm{~mL} / \mathrm{g} \times 0.47 \mathrm{~g} / \mathrm{mL}=67
$$

Thus, up to 67 column volumes of Envelope C (Tank AN-102) salt solution could be processed with SuperLig ${ }^{\circledR} 639$ resin before $50 \%$ breakthrough occurs.

\subsection{Cesium Column Loading}

The cesium decontamination experiment for Envelope $\mathrm{C}$ (AN-102) was conducted $\sim 2$ months after completion of the Envelope A (AN-103) cesium column run. Envelope $\mathrm{C}$ feed was subjected to $\mathrm{Sr} / \mathrm{TRU}$ precipitation and filtration prior to the ion exchange column run. The Sr/TRU precipitation was performed $\sim 6$ weeks prior to the ion exchange column test. In this regard, the test did not mimic plant operations as it is unlikely that any oxidant from the $\mathrm{Sr}$ TRU precipitation would have still been present after the long storage period. A separate test has been performed to confirm that the resin is not significantly impacted by the Sr/TRU removal process, and will be reported in a subsequent document. The filtrate from Sr/TRU precipitation and filtration was a dark, 
brown solution with a measured density of $1.234 \mathrm{~g} / \mathrm{mL}$. Analysis of the filtrate solution indicated that the nitrate $\left(\mathrm{NO}_{3}{ }^{-}\right)$, potassium $\left(\mathrm{K}^{+}\right)$, and hydroxide $(\mathrm{OH})$ concentrations were $1.89 \mathrm{E}+00,2.92 \mathrm{E}-02$, and $1.69 \mathrm{E}+00 \mathrm{M}$, respectively. The total organic carbon (TOC), uranium and chloride ion concentrations in the filtrate were 2.25E+04, 1.23E+01, and $4.35 \mathrm{E}-02 \mathrm{mg} / \mathrm{L}$, respectively. The $\mathrm{Na}^{+}$concentration measured by inductively coupled plasma - atomic emission spectroscopy (ICP-AES) was $5.98 \mathrm{M}$, thus giving $\mathrm{Na} / \mathrm{Cs}$ and $\mathrm{K} / \mathrm{Cs}$ ratios of $9.42 \mathrm{E}+04$ and $4.62 \mathrm{E}+02$, respectively. The breakthrough data for cesium on SuperLig ${ }^{\circledR} 644$ resin are shown in Table 7. Figure 3 shows the Cs-137 concentration profile as a function of the effluent column volumes from the lead ion exchange column. It can be seen that an $11 \%$ breakthrough occurred for Envelope C (AN-102) solution at 85 column volumes and the guard column exhibited a less than $0.1 \%$ breakthrough at 53 column volumes; the run was terminated due to insufficient feed. The breakthrough curves in Figure 3 indicate that the cesium removal from Envelope C (AN-107) was slightly better than from feed sample (AN-102). This may be attributed to slightly higher potassium concentration in this sample (AN-102); compared to $\mathrm{AN}-107$, or the lower $\mathrm{Na} / \mathrm{Cs}$ mole ratio for the $\mathrm{AN}-107$ sample $(6.89 \mathrm{E}+04)$ versus that of the AN-102 sample (9.42E+04, assuming $\mathrm{Cs}^{137}$ is $25 \%$ of the total cesium in each sample).

Figure 4 shows the results of the sodium and free hydroxide analyses for the feed displacement and rinse effluent samples. The feed displacement or wash solution $(2 \mathrm{CV}$ of $0.1 \mathrm{M} \mathrm{NaOH})$ reduced the $\mathrm{Na}^{+}$and hydroxide concentrations from $\sim 6$ to $1.3 \mathrm{M}$ and $\sim 1.69$ to $0.27 \mathrm{M}$, respectively. The de-ionized water rinse that followed the feed displacement had residual $\mathrm{Na}^{+}$and free hydroxide concentrations of $0.088 \mathrm{M}$ and $0.11 \mathrm{M}$, respectively, indicating additional water rinsing may be necessary to achieve good displacement of the $0.1 \mathrm{M} \mathrm{NaOH}$ solution from the column. The percent volume change of the resin between the acid and caustic cycles was in the range 30 to $40 \%$; a $10 \%$ reduction of the resin volume observed during the loading (vs. pre-conditioning) showed no detrimental effect on the resin performance. This swelling and shrinking behavior is consistent with previous data. ${ }^{1}$ There was no visible indication of resin decomposition as the characteristic brown color of the resin was absent from column effluent, rinse, and regenerate solutions.

\subsection{Cesium Column Elution}

The results for cesium elution from SuperLig ${ }^{\circledR} 644$ resin with dilute nitric acid $\left(0.5 \mathrm{M} \mathrm{HNO}_{3}\right)$ at $1 \mathrm{CV} / \mathrm{h}$ are shown in Table 8 and Figure 5. Figure 5 reveals that the dilute nitric acid $(0.5 \mathrm{M})$ was effective for nearly complete removal of cesium from the resin. The elution curve exhibits four regions, namely: neutralization of residual $0.1 \mathrm{M}$ $\mathrm{NaOH}$ solution, peak, exponential decay, and tailing. The neutralization region at the left bottom end of the curve represents several column volumes of acid eluting very little cesium. During this period, the acid is probably reacting with the residual hydroxide ions in the liquid and the hydrogen ions are starting to replace sodium ions on the resin. The peak region of the curve shows a sharp peak at 5 column volumes, during which almost $78 \%$ of the removable cesium in the column was eluted. The exponential decay region that follows the peak region shows a significant drop in cesium concentration within a 
few column volumes of the acid. The final region of elution curve shows a small tailing effect. Less than $2 \%$ of the initial cesium concentration remained in the eluent after 13 column volumes had passed through the column. The small tailing effect may be attributed to incomplete and uneven cesium loading on the resin. Due to high affinity of the resin, the cesium may have been loaded in a narrow layer on the top of the resin bed. It has been observed that when the resin is fully loaded with cesium, less difficulty is observed in completely eluting the cesium. Also, during elution a rapid shrinkage of the resin could cause a diminished diffusion velocity of cesium ions in the resin and, consequently, lower the rate of elution. The volume of the resin decreased from 6.2 to $4.3 \mathrm{~mL}$ at the end of elution.

\subsection{Technetium Column Loading}

The planned treatment process removes cesium before technetium. Thus, at the conclusion of the cesium column run and after reviewing the cesium concentration profile data and confirming that the decontaminated effluent fractions from guard column met pretreatment radionuclide acceptance limits, all effluent fractions were combined. About $500 \mathrm{~mL}$ of the combined solution was pumped down-flow at $3 \mathrm{CV} / \mathrm{h}$ into the technetium ion exchange columns. The sodium $\left(\mathrm{Na}^{+}\right)$and nitrate $\left(\mathrm{NO}_{3}{ }^{-}\right)$concentrations in the feed sample (AN-102) to the ion exchange columns were measured by inductively coupled plasma - atomic emission spectroscopy (ICP-AES) and ion chromatography (IC), respectively. The values measured for $\mathrm{Na}^{+}$and $\mathrm{NO}^{-}$were 5.98 and $1.89 \mathrm{M}$, giving a $\mathrm{NO}_{3} / \mathrm{Tc}$ ratio of $2.59 \mathrm{E}+04$ in the feed. The nitrate anion (NO3) primarily competes with the pertechnetate anion to bind on the SuperLig ${ }^{\circledR} 639$ resin. The results for Tc-99 breakthrough the ion exchange columns are presented in Table 9. The reported results assume all observed $\mathrm{m} / \mathrm{z} 99$ is due to technetium and any observed ruthenium spectra are not typical of natural ruthenium, but may be exclusively fission product ruthenium.

Figure 6 shows a plot of the effluent Tc-99 concentration in $\mu \mathrm{g} / \mathrm{L}$ as a function of the number of column volumes processed. It can be seen, as expected, that the large portion of non-pertechnetate form of technetium in the feed (up to 70\%) had passed through both the lead and lag columns. This result indicates that slightly more was removable than was shown by the batch recontact distribution coefficient results, which revealed that less than $22.5 \%$ of the technetium is extracted by the resin. The data in Figure 6 show a significant scatter, the cause of which is not known but may be related to wall effects or dilution effects. The average resin-particle diameter for SuperLig ${ }^{\circledR} 639$ was reported by the vendor to be approximately $500 \mu \mathrm{m}$. With a column inside diameter of 11 $\mathrm{mm}$, the bed diameter is about 20 resin-particle diameters. Although this situation is less than ideal ( $>30$ particle diameters) it was necessary due to the limited sample size and the desire to obtain a breakthrough profile. The results thus yield a conservative estimate of the full-scale column performance. Smaller resin particles could enhance the kinetics of the exchange process and prevent wall effects, but it could not be directly scaled up. Using smaller particle sizes for the full-scale unit would cause a higher pressure drop. The lead column loading data indicated an anomalous low Tc concentration at 20 column volumes. There is no apparent cause for this, but may be the result of analytical or dilution error. 
Figure 7 shows the results of the sodium and free hydroxide analyses for the feed displacement and rinse effluent samples from technetium ion exchange columns. The feed displacement or wash solution ( $3 \mathrm{CV}$ of $0.1 \mathrm{M} \mathrm{NaOH}$ ) reduced the $\mathrm{Na}^{+}$and free hydroxide concentrations from $\sim 5.57$ and $0.82 \mathrm{M}$ to 0.795 and $0.31 \mathrm{M}$, respectively. The de-ionized water rinse that followed the feed displacement had reduced the $\mathrm{Na}^{+}$and free hydroxide concentrations to 0.11 and $0.1 \mathrm{M}$, respectively.

\subsection{Technetium Column Elution}

The results for technetium elution from SuperLig ${ }^{\circledR} 639$ lead column are presented in Table 10. The elution was performed with de-ionized water at approximately $1 \mathrm{CV} / \mathrm{h}$. The elution profile of the SuperLig $639^{\circledR}$ is shown in Figure 8. It should be pointed out that the first three column volumes in the abscissa of Figure 8 represent a de-ionized water "rinse" at $3 \mathrm{CV} / \mathrm{h}$, which in effect is the beginning of the elution cycle. Figure 8 shows that the technetium concentration of the eluate reached a peak corresponding to 2.7 times the feed concentration at 6 column volumes, then exponentially decreased to less than $4 \%$ of the feed concentration up to 12 column volumes. Elution is considered complete when less than $1 \%$ of the total feed technetium concentration remains in the eluate, and this occurred at $22 \mathrm{CV}$. The elution efficiency for Tc-99 was 97\% in the first 10 column volumes of the eluate. This is in agreement with previously observed elution efficiency scheme for SuperLig $639^{\circledR}$ with Envelope C, in which $98 \%$ of Tc-99 loaded on the resin was stripped within 10 column volumes. ${ }^{5}$ Due to the unavailability of at-line Tc monitor/analyzer, it was not possible to determine when elution was complete, so the elution was continued for up to 41.9 column volumes and samples were submitted for analysis. The last 18 column volumes of elution volume stripped the technetium remaining on the resin from 0.4 to $0.16 \%$ (i.e. $4.0 \mathrm{E}-03 \mathrm{C} / \mathrm{Co}$ to $1.6 \mathrm{E}-03 \mathrm{C} / \mathrm{Co}$ ). Although the technetium elution rate for SuperLig ${ }^{\circledR} 639$ resin seems to be better than expected, the resin was not fully loaded with technetium, and therefore, the data need to be interpreted with caution. Also, basing the elution on "pertechnetate only", rather than total technetium, shows that the pertechnetate elution was not complete until 41.9 column volumes.

\subsection{Product Characterization}

The characterization results for decontaminated product and concentrated cesium and technetium eluate products are shown in Tables 11, 12, and 13, respectively. In the tables, the radionuclides, elemental compositions, and anion compounds of the final products were also presented. The percent removal of Cs-137 and Tc-99 from Envelope C (AN-102) salt solution were $99.93 \pm 0.03 \%$ and $45.7 \pm 2.08 \%$, respectively. The percent removals of cesium and technetium were calculated from the mean concentrations of two measurements each for Cs-137 and Tc-99 both in the feed and product solutions. The standard deviation $(\sigma)$ for the percent removal was calculated from equation (8). The error in the percent removal was calculated assuming a variance of two standard deviations $(2 \sigma)$ in the average. 


$$
\sigma^{2}=\left(\frac{100}{C_{i}}\right)^{2} x\left[\left(\left(s_{C f}\right)^{2}+\left(\frac{C_{f}}{C_{i}}\right)^{2} x\left(S_{C i}\right)^{2}\right)\right]
$$

where $\mathrm{S}_{\mathrm{cf}}=$ standard deviation of final concentration,

$\mathrm{S}_{\mathrm{ci}}=$ standard deviation of initial concentration,

$\mathrm{C}_{\mathrm{f}}=$ final concentration, and $\mathrm{C}_{\mathrm{i}}=$ initial concentration

- The concentrations of Cs- 137 and Tc- 99 in the decontaminated product were $1.10 \mathrm{E}-01$ and $4.3 \mathrm{E}-02 \mu \mathrm{Ci} / \mathrm{mL}$, respectively. The concentration of both radionuclides are lower than the maximum content allowed by immobilized Law activity waste (ILAW) acceptance criteria. The chemical species in the final decontaminated product were generally as expected. Uranium concentration in the final decontaminated product by inductively coupled plasma - mass spectroscopy (ICP-MS) was only $6.2 \mathrm{E}-01 \mathrm{mg} / \mathrm{L}$, which indicates a significant removal of uranium as compared to initial concentration of $1.23 \mathrm{E}+01 \mathrm{mg} / \mathrm{L}$. The concentration of uranium in the composite eluate solution was $1.68 \mathrm{E}+01 \mathrm{mg} / \mathrm{L}$.

The results for characterization of cesium and technetium eluate products are shown in Tables 12 and 13 . The chemical species in the eluate products were generally as expected, with the exception of uranium, total organic carbon and chloride ion. The chloride appears to be concentrated both by the cesium and technetium ion exchange resin. Observations of high chloride ion concentration by the SuperLig ${ }^{\circledR}$ resins was previously reported by us. ${ }^{4}$ Similarly, concentration of uranium by SuperLig ${ }^{\circledR} 644$ from Envelope $\mathrm{C}$ has also been observed previously. ${ }^{4}$ However, the amount of uranium in this eluate is much lower than from tank AN-107. Presumably, the initial concentration of uranium is much lower in this AN-102 sample, although it was not directly measured in the previous work. In addition, the Sr/TRU removal process further reduced the uranium concentration in this $\mathrm{AN}-102$ sample. Chromium has often been observed to be concentrated in cesium eluate, but was not observed in this case, based on comparison to other residuals from the feed such as aluminium.

The total organic carbon (TOC) in the cesium and technetium eluate products were reported as 470 and $221 \mathrm{mg} / \mathrm{L}$, respectively. However, duplicate samples varied by a factor of 2.8 for both cesium and technetium eluates. The poor precision between the samples and duplicates for TOC analyses indicates the difficulty in measuring this parameter in this complex matrix.

\subsection{Spent Resin Digestion and Analyses}

The spent SuperLig ${ }^{\circledR} 644$ and 639 resins that were used for decontaminating Envelope A (AN-103) and C (AN-102) salt solutions were digested and the residual analytes were measured by ICP-ES, ICP-MS, AA, and gamma scan. Prior to resin digestion, the resins were regenerated with $6 \mathrm{CV}$ of $1.0 \mathrm{M} \mathrm{NaOH}$ (SuperLig ${ }^{\circledR}$ 639) and 
$0.25 \mathrm{M} \mathrm{NaOH}$ (SuperLig ${ }^{\circledR}$ 644), then rinsed with $9 \mathrm{CV}$ of de-ionized water. The resins were then slurried out from the columns into filter units and subjected very briefly to vacuum just long enough to remove standing liquids. The resin digestion was performed by heating $0.1 \mathrm{~g}$ of the resin with $3 \mathrm{ml}$ of conc. $\mathrm{HNO}_{3}$ in the Parr bomb at $150^{\circ} \mathrm{C}$ for 1.5 hours to destroy the organic. The digested solution was then cooled to ambient temperature and diluted with water to $10 \mathrm{~mL}$ final volume.

The analytical results for digested resins are presented in Table 14. The residual radionuclides (Cs-137 and Tc-99) on SuperLig ${ }^{\circledR} 639$ resin were as expected. However, the Cs-137 content in the spent SuperLig 644 resin was $7.4 \mu \mathrm{Ci} / \mathrm{g}$ despite the fact that the elution data showed less than $1 \%$ of initial $\mathrm{Cs}$ in Envelope $\mathrm{C}$ salt solution (i.e. 1.80 $\mu \mathrm{Ci} / \mathrm{mL}$ ) was in the eluate at the end of elution. The residual concentrations of RCRA characteristically hazardous elements were below the theoretical TCLP limit. The theoretical TCLP limit was calculated assuming all of the metal ion would dissolve in the TCLP test and a solid: liquid ratio of $50 \mathrm{~g}$ to $1 \mathrm{~L}$.

\subsection{CONCLUSION}

Cesium and technetium removal from Envelope $\mathrm{C}$ salt solution from Hanford Tank AN-102 was accomplished using IBC manufactured SuperLig ${ }^{\circledR}$ ion exchange resins. The cesium distribution coefficient for SuperLig ${ }^{\circledR} 644$ resin was $759 \mathrm{~mL} / \mathrm{g}$. The projected column volume of feed to process at $50 \%$ breakthrough was estimated as 303 column volumes, although prior work indicated that only $37 \%$ of this value $(112 \mathrm{CV})$ would be reached. The resin achieved $11 \%$ breakthrough by the time the available feed sample was consumed at 85 column volumes. Nitric acid $(0.5 \mathrm{M})$ was effective to elute cesium from the resin with less than $0.2 \%$ of the cesium remaining in the effluent from the column at 18 column volumes. The elution profile exhibited a small tailing effect. The percent removal of cesium from Envelope $\mathrm{C}$ by two-column (lead/lag) configuration containing SuperLig ${ }^{\circledR} 644$ resin was $99.93 \pm 0.03 \%$.

The distribution coefficient for technetium on SuperLig ${ }^{\otimes} 639$ resin was $16 \mathrm{~mL} / \mathrm{g}$. The calculated $\mathrm{K}_{\mathrm{d}}$ value for the pertechnetate (anion) form was $142 \mathrm{~mL} \mathrm{~g}$. The projected column volume to process at $50 \%$ breakthrough for extractable pertechnetate was 67 . As expected, an immediate breakthrough of the non-extractable, non-pertechnetate form of technetium was observed through both lead and lag columns. Elution of technetium from the resin with de-ionized water at $1 \mathrm{CV} / \mathrm{h}$ was efficient with $97 \%$ recovery up to 10 column volumes and less than $1 \%$ of Tc remaining on the resin after 22 column volumes. The percent removal of technetium from Envelope C by SuperLig ${ }^{\circledR} 639$ was $45.74 \pm 2.08$ $\%$. This is approximately twice the percent pertechnetate in the salt solution $(22.5 \%)$ determined through sequential batch re-contacts.

Characterization results showed that the $\mathrm{Cs} / \mathrm{Na}$ and $\mathrm{Tc} / \mathrm{Na}$ mole ratios in the final decontaminated product were $2.03 \mathrm{E}-05 \mathrm{Ci} / \mathrm{mole} \mathrm{Na}$ and $8.29 \mathrm{E}-06 \mathrm{Ci} / \mathrm{mole} \mathrm{Na}$, respectively. These results are within the range of $\mathrm{Cs}$ and $\mathrm{Tc}$ limits for the immobilized 
law activity waste glass ${ }^{6}$. The chemical compositions in the final decontaminated product and eluate concentrates were as expected with the exception of uranium, TOC, and chloride ions which were concentrated by the cesium ion exchange resin and later eluted by nitric acid. The residual analytes in the digested spent resins were generally below their detection limits, with the exception of Cs in the spent SuperLig ${ }^{\circledR} 644$ resin.

\subsection{APPROVALS}

\section{Design Check}

\begin{tabular}{|c|c|}
\hline Mie, ithonks & $5 \longdiv { 9 1 0 0 }$ \\
\hline M. C. Thompson & Date \\
\hline
\end{tabular}

\subsection{REFERENCES}




\subsection{REFERENCES}

1. Hassan, N. M., King W. D. and McCabe, D. J., small-scale ion exchange removal of cesium and technetium from Hanford Tank 241-AN-103 (u), SRTC-BNF0198, Revision 0, August 25, 1999.

2. Hassan, N. M. and McCabe D. J., Hanford Envelope C Tank Waste Ion Exchange Column Study (U), SRTC-BNFL-019, Revision 0, October 24, 1997.

3. McCabe, D. J, Hassan, N. M. and Thompson, M. C., SuperLig ${ }^{\circledR} 644$ Pretreatment Requirement for Hanford Privatization Samples (U), SRTC-BNFL-012, Revision 0 , July 21,1997 .

4. Hassan, N. M, King, W. D., and McCabe, D. J, SuperLig ${ }^{\circledR}$ Ion Exchange Resin Swelling and Buoyancy Study (U), BNF-003-98-0051, Revision 0, March 25, 1999

5. Nash, C. A., S.W. Rosencrance, B.R. Wilmarth, Entrained Solids, StrontiumTransuranic Precipitation, and Crossflow Filtration of AN102 Small C, BNF003-98-0218.

6. USDOE Contract No. DE-AC27-96RV13308 (formerly contract no. DE-AC0696RL13308), Specification 2: Immobilized Low-Activity Waste.

\section{DISTRIBUTION:}

M. E. Johnson, BNFL, Inc.

S.T. Wach, 773-42A

M. C. Thompson, 773-A

H. F. Sturm, 773-A

L.M. Nelson, 773-43A

J. L. Steimke, 786-5A

D. Kurath, PNNL

BNFL Part B Document File, B. Skwarek, 773-41A 
Table 1. Small Envelope C Filtrate characterization Data

\begin{tabular}{|c|c|c|}
\hline Constituent ions & $\begin{array}{l}\text { Tank-241-AN-102 } \\
\text { concentration [M] }\end{array}$ & $\begin{array}{l}\text { Tank-241-AN-107 } \\
\text { Concentration [M] }\end{array}$ \\
\hline \multicolumn{3}{|l|}{ Cations, $M$} \\
\hline$\left[\mathrm{Na}^{+}\right]$ & 5.98 & 5.71 \\
\hline [Al] & $2.72 \mathrm{E}-01$ & $2.1 \mathrm{E}-3$ \\
\hline [Ca] & $5.14 \mathrm{E}-03$ & $8.6 \mathrm{E}-3$ \\
\hline$[\mathrm{Cr}]$ & $1.69 \mathrm{E}-03$ & $1.1 \mathrm{E}-3$ \\
\hline$[\mathrm{Pb}]$ & $4.03 \mathrm{E}-04$ & $7.6 \mathrm{E}-3$ \\
\hline$[\mathrm{Zn}]$ & $<5.05 \mathrm{E}-05$ & $1.0 \mathrm{E}-4$ \\
\hline$\left[\mathrm{K}^{+}\right]$ & $2.92 \mathrm{E}-02$ & $2.6 \mathrm{E}-2$ \\
\hline $\mathrm{U}-238$ mass $(\mathrm{mg} / \mathrm{L})$ & $1.23 \mathrm{E}+01$ & n. $m$ \\
\hline \multicolumn{3}{|l|}{ Anions, $M$} \\
\hline$\left[\mathrm{NO}_{3}^{-}\right]$ & $1.89 \mathrm{E}+00$ & $2.48 \mathrm{E}+00$ \\
\hline$\left[\mathrm{NO}_{2}{ }^{-}\right]$ & $8.32 \mathrm{E}-01$ & $8.29 \mathrm{E}-01$ \\
\hline$\left[\mathrm{Cl}^{-}\right]$, by IC & $4.35 \mathrm{E}-02$ & $3.3 \mathrm{E}-02$ \\
\hline$\left[F^{-}\right]$, by IC & $4.11 \mathrm{E}-02$ & $6.3 \mathrm{E}-02$ \\
\hline$\left[\mathrm{SO}_{4}^{-2}\right]$ & $6.20 \mathrm{E}-02$ & $6.3 \mathrm{E}-02$ \\
\hline$\left[\mathrm{PO}_{4}^{-2}\right]$ & $<1.26 \mathrm{E}-02$ & $6.3 \mathrm{E}-02$ \\
\hline formate & $\mathrm{nm}$ & $1.33 \mathrm{E}-01$ \\
\hline $\mathrm{OH}^{-}$(Free) & $1.69 \mathrm{E}+00$ & $3.94 \mathrm{E}-01$ \\
\hline \multicolumn{3}{|l|}{ Radionuclides, $\mathrm{uCi} / \mathrm{mL}$} \\
\hline Cs-137 & $1.90 \mathrm{E}+02$ & $246^{*}$ \\
\hline Am-241 & $1.50 \mathrm{E}-02$ & $<0.29^{*}$ \\
\hline Sr-90 & $1.65 \mathrm{E}+00$ & $70.3^{*}$ \\
\hline alpha & $1.78 \mathrm{E}-02$ & $0.55^{*}$ \\
\hline Tc (calc'd, mass 99) & $7.80 \mathrm{E}-02$ & $0.051^{*}$ \\
\hline \multicolumn{3}{|l|}{ Total carbon } \\
\hline TIC & $0.65 \mathrm{M}$ & $0.95 \mathrm{M}^{*}$ \\
\hline TOC & $1.88 \mathrm{M}$ & $2.68 \mathrm{M}^{*}$ \\
\hline Density $(g / m L)$ & $1.23 \mathrm{E}+00$ & 1.276 \\
\hline
\end{tabular}

* Characterization before dilution, corrected for dilution by calculation 
Table 2. Physical properties of "as received" SuperLig" resin

\begin{tabular}{|l|l|c|c|c|c|}
\hline Resin & Batch \# & $\begin{array}{c}\text { Particle } \\
\text { density }(\mathrm{g} / \mathrm{mL})\end{array}$ & $\begin{array}{c}\text { Bulk density } \\
(\mathrm{g} / \mathrm{mL})\end{array}$ & $\begin{array}{c}\text { \% Water } \\
\text { content }\end{array}$ & F-Factor \\
\hline SuperLig 644 & $981020 \mathrm{MB} 48-563$ & 1.549 & 0.758 & 9.6 & 0.904 \\
\hline SuperLig 639 & 981015 DHC-720011 & 1.147 & 0.468 & 1.3 & 0.987 \\
\hline
\end{tabular}

Table 3. Sieve analysis of SuperLig 639 resin batch batch \#981015DHC-720011

\begin{tabular}{|c|c|c|c|c|c|c|}
\hline & & wt. of fractions (g) & \multicolumn{2}{|c|}{ w. \% } & ave. wt. \% \\
\hline Screen Mesh & Opening & Sample 1 & Sample 2 & Sample 1 & Sample 2 & $(\%)$ \\
\hline 10 & $>200 \mathrm{~mm}$ & & & & & \\
\hline 30 & $>600$ & 4.37 & 4.169 & 87.35 & 67.80 & 77.57 \\
\hline 40 & $>425$ & 0.574 & 0.722 & 11.47 & 11.74 & 11.61 \\
\hline 50 & $>300$ & 0.035 & 0.054 & 0.70 & 0.88 & 0.79 \\
\hline 70 & $>212$ & 0.01 & & 0.20 & & 0.10 \\
\hline 80 & $>180$ & 0.007 & & & & \\
\hline 100 & $>150$ & & & & & \\
\hline 230 & $>62$ & & & & & \\
\hline & total & 5.00 & 4.945 & 99.7 & 98.7 & 99.2 \\
\hline
\end{tabular}

wt. original sample \# $1=5.003 \mathrm{~g}$; wt. sample $\# 2=5.008 \mathrm{~g}$

Table 4. Sieve analysis of SuperLig 644 resin batch batch \# $981020 \mathrm{mb48-563}$

\begin{tabular}{|c|c|c|c|c|c|c|}
\hline & & \multicolumn{2}{|c|}{ wt. of fractions (g) } & \multicolumn{2}{|c|}{$\mathrm{w}=\%$} & ave. wt. \% \\
\hline Screen Mesh & Opening & Sample 1 & Sample 2 & Sample 1 & Sample 2 & $(\%)$ \\
\hline 10 & $>200 \mathrm{~mm}$ & $\mathbf{0}$ & 0 & 0 & & 0 \\
\hline 30 & $>600$ & 2.9342 & 2.8406 & 59.77 & 54.89 & 57.33 \\
\hline 40 & $>425$ & 1.1143 & 1.2821 & 22.70 & 24.77 & 23.73 \\
\hline 50 & $>300$ & 0.6389 & 0.7456 & 13.01 & 14.41 & 13.71 \\
\hline 70 & $>212$ & 0.2115 & 0.3072 & 4.31 & 5.94 & 5.12 \\
\hline 80 & $>180$ & 0.0105 & 0 & 0.21 & 0.00 & 0.11 \\
\hline 100 & $>150$ & & & & & \\
\hline 230 & $>62$ & & & & & \\
\hline & total & 4.9094 & 5.1755 & 99.8 & 100 & 99.9 \\
\hline
\end{tabular}

wt. original sample \# $1=5.003 \mathrm{~g}$; wt. sample \#2=5.1758 g 
Table 5. Batch distribution coefficient data for Cs on SuperLig ${ }^{\circledR} 644$ resin

\begin{tabular}{|c|c|c|c|c|c|c|c|c|c|}
\hline Sample ID & $\begin{array}{l}\text { solution } \\
\text { mass }(\mathrm{g})\end{array}$ & $\begin{array}{c}\text { resin } \\
\text { mass }(\mathrm{g})\end{array}$ & $\begin{array}{l}\text { solution } \\
\text { vol.(mL) }\end{array}$ & $\begin{array}{l}\text { phase } \\
\text { ratio }\end{array}$ & $\begin{array}{l}{[\mathrm{Cs}-137]} \\
(\mathrm{uCi} / \mathrm{mL})\end{array}$ & $\begin{array}{c}{[\mathrm{Cs}-137]} \\
\text { Removal } \\
(\mathrm{uCi} / \mathrm{mL})\end{array}$ & $\begin{array}{c}\mathrm{Kd} \\
(\mathrm{mL} / \mathrm{g})\end{array}$ & $\begin{array}{l}\text { ave. } \mathrm{Kd} \\
(\mathrm{mL} / \mathrm{g})\end{array}$ & $\begin{array}{c}\text { ave. } \\
(\% \mathrm{R})\end{array}$ \\
\hline \multicolumn{10}{|l|}{ Standard Kd } \\
\hline BNF-M1800-AN102-1 & 14.37 & na & 11.68 & na & 199.3 & na & na & na & na \\
\hline BNF-M1800-AN102-2 & 14.726 & na & 11.97 & na & 181.4 & na & na & na & na \\
\hline BNF-M1800-S644-1 & 14.799 & 0.1207 & 12.01 & 99.5 & 23.52 & 166.8 & 780.8 & & \\
\hline BNF-M1800-S644-1D & 14.552 & 0.1204 & 11.81 & 98.1 & 24.43 & 165.9 & 737.1 & 758.9 & 88 \\
\hline \multicolumn{10}{|l|}{$1^{\text {st }}$. Recontact Kd } \\
\hline BNF-M1800-S644-1R-1 & 10.33 & 0.1003 & 8.398 & 83.7 & 1.486 & 22.034 & 1373 & & \\
\hline BNF-M1800-S644-1R-ID & 10.991 & 0.1004 & 8.936 & 89.0 & 1.619 & 22.81 & 1387 & 1380 & 94 \\
\hline \multicolumn{10}{|l|}{$2^{\text {nd }} \cdot$ Recontact Kd } \\
\hline BNF-M1800-S644-2R-1 & 6.18 & 0.0513 & 5.024 & 97.9 & 0.106 & 1.380 & 1410 & & \\
\hline BNF-M1800-S644-2R-2 & 6.203 & 0.0509 & 5.043 & 99.1 & 0.124 & 1.495 & 1321 & 1366 & 93 \\
\hline Cs spiked Kd test ${ }^{\ddagger}$ & & & & & Cs (ug/L) & Cs (ug/L) & & & \\
\hline BNF-C320-S644-spk-1 & 12.73 & 0.1003 & 10.35 & 103 & 57402 & 147458 & 293.3 & & \\
\hline BNF-C320-S644-spk-1D & 12.78 & 0.1009 & 10.39 & 103 & 55093 & 149767 & 309.7 & 301.5 & 73 \\
\hline BNF-C320-Cs-spk-F2 & 11.47 & na & 9.324 & na & 204860 & na & & & \\
\hline
\end{tabular}

$\mp 20 \mu \mathrm{L}$ of $1 \mathrm{M} \mathrm{Cs}(\mathrm{NO} 3)$ was added into $30 \mathrm{~mL}$ of the diluted $\mathrm{AN}-102$ sample.

F-factor $=0.904 ;$ Temperature $=26 \pm 1^{\circ} \mathrm{C}$; contact time $=24 \pm 1 \mathrm{~h}$; batch $\#$ : $981020 \mathrm{MB} 48-563$

na $=$ not applicable

Cs Isotopic ratio

Cs-133

Cs-135

Cs-137

Total Cs avg. values (ppb)

$4.03 \mathrm{E}+03$

$1.35 \mathrm{E}+03$

$1.92 \mathrm{E}+03$

$7.28 \mathrm{E}+03$ 
Table 6. Batch distribution coefficients for technetium on SuperLig $^{\circledR} 639$ resin

\begin{tabular}{|c|c|c|c|c|c|c|c|c|c|}
\hline Sample ID & $\begin{array}{c}\text { Solution } \\
\text { wt. (g) }\end{array}$ & $\begin{array}{c}\text { Resin } \\
\operatorname{mass}(\mathrm{g})\end{array}$ & $\begin{array}{c}\text { Volume } \\
(\mathrm{mL})\end{array}$ & $\begin{array}{c}\text { phase } \\
\text { ratio }\end{array}$ & $\begin{array}{c}{[\mathrm{Tc}-99]} \\
(\mu \mathrm{g} / \mathrm{L})\end{array}$ & $\begin{array}{c}\text { Tc-99 } \\
\text { Removed } \\
\text { (ug/L) }\end{array}$ & $\begin{array}{c}\mathrm{Kd} \\
(\mathrm{mL} / \mathrm{g})\end{array}$ & $\begin{array}{l}\text { ave. Kd } \\
(\mathrm{mL} / \mathrm{g})\end{array}$ & $\begin{array}{c}\% \\
\text { (R) }\end{array}$ \\
\hline \multicolumn{10}{|l|}{ Standard Kd } \\
\hline BNF-M1800-F-1 & 14.37 & NA & 11.68 & na & 4713 & na & na & na & na \\
\hline BNF-M1800-F-1D & 14.726 & NA & 11.9 & na & 4451 & na & na & na & na \\
\hline BNF-M1800-S39-1 & 15.173 & 0.1204 & 12.34 & 102.5 & 3951 & 632 & 16.60 & & \\
\hline BNF-M1800-S39-1D & 15.474 & 0.1203 & 12.58 & 104.6 & 4032 & 550 & 14.45 & 15.53 & 87 \\
\hline \multicolumn{10}{|l|}{$1^{\text {st }}$. Recontact Kd } \\
\hline BNF-M1800-S39-1R-1 & 10.913 & 0.1007 & 8.872 & 88.11 & 3641 & 309 & na & na & na \\
\hline BNF-M1800-S39-1R-1D & 11.076 & 0.1004 & 9.005 & 89.69 & 3498 & 534 & na & na & na \\
\hline \multicolumn{10}{|l|}{$2^{\text {nd }}$. Recontact Kd } \\
\hline BNF-M1800-S39-2R-1 & 6.160 & 0.0510 & 5.008 & 98.20 & 3548 & na & na & na & na \\
\hline BNF-M1800-S39-2R-1D & 6.162 & 0.0510 & 5.01 & 98.23 & 3553 & na & na & na & na \\
\hline
\end{tabular}

F-factor $=0.987 ;$ Temperature $=26 \pm{ }^{\circ} \mathrm{C} ;$ contact time $=24 \pm 1 \mathrm{~h}$; batch \#: $981015 \mathrm{DHC}-720011$

$\uparrow 0.5 \mathrm{~mL}$ of $20 \mu \mathrm{Ci} / \mathrm{mLTc}$ was added into $30 \mathrm{~mL}$ of Hanford $\mathrm{AN}-102$ sample.

na $=$ not applicable

Table 7. Cesium Ion Exchange column loading profiles

\begin{tabular}{|l|c|c|c|}
\hline Lead column sample ID & $\begin{array}{c}\text { \#CV processed } \\
\text { (lead column) }\end{array}$ & $\begin{array}{c}\text { Cs-137 Effluent } \\
(\mu \mathrm{Ci} / \mathrm{mL})\end{array}$ & $\begin{array}{c}\text { Concentration } \\
\text { profile (C/Co) }\end{array}$ \\
\hline BNF-C320-CsIX-Cr4-F-1 & na & 182.24 & na \\
\hline BNF-C320-CsIX-Cr4-F-2 & na & 181.95 & na \\
\hline BNF-C320-CsIXEFF-Cr4-LCS1 & 5 & $4.097 \mathrm{E}-02$ & $2.25 \mathrm{E}-04$ \\
\hline BNF-C320-CsIXEFF-Cr4-LCS2 & 10 & $1.084 \mathrm{E}-01$ & $5.96 \mathrm{E}-04$ \\
\hline BNF-C320-CsIXEFF-Cr4-LCS3 & 20 & $4.495 \mathrm{E}-01$ & $2.47 \mathrm{E}-03$ \\
\hline BNF-C320-CsIXEFF-Cr4-LCS4 & 30 & $1.692 \mathrm{E}+00$ & $9.29 \mathrm{E}-03$ \\
\hline BNF-C320-CsIXEFF-Cr4-LCS5 & 40 & $7.362 \mathrm{E}+00$ & $4.04 \mathrm{E}-02$ \\
\hline BNF-C320-CsIXEFF-Cr4-LCS6 & 50 & $9.085 \mathrm{E}+00$ & $4.99 \mathrm{E}-02$ \\
\hline BNF-C320-CsIXEFF-Cr4-LCS7 & 60 & $8.236 \mathrm{E}+00$ & $4.52 \mathrm{E}-02$ \\
\hline BNF-C320-CsIXEFF-Cr4-LCS8 & 70 & $1.555 \mathrm{E}+01$ & $8.54 \mathrm{E}-02$ \\
\hline BNF-C320-CsIXEFF-Cr4-LCS9 & 80 & $1.912 \mathrm{E}+01$ & $1.05 \mathrm{E}-01$ \\
\hline BNF-C320-CsIXEFF-Cr4-LCS10 & 85 & $2.107 \mathrm{E}+01$ & $1.16 \mathrm{E}-01$ \\
\hline Lag column sample ID & & & $6.31 \mathrm{E}-05$ \\
\hline BNF-C320-CsIXEFF-Cr4-GCV-s1 & 13 & $1.149 \mathrm{E}-02$ & $2.90 \mathrm{E}-04$ \\
\hline BNF-C320-CsIXEFF-Cr4-GCV-s2 & 27 & $5.287 \mathrm{E}-02$ & $2.05 \mathrm{E}-03$ \\
\hline BNF-C320-CsIXEFF-Cr4-GCV-s3 & 39 & $3.741 \mathrm{E}-01$ & $1.25 \mathrm{E}-03$ \\
\hline BNF-C320-CsIXEFF-Cr4-GCV-s4 & 53 & $2.273 \mathrm{E}-01$ &
\end{tabular}


Table 8. Cesium elution profile for lead column

\begin{tabular}{|c|c|c|c|}
\hline Lead column sample ID & $\begin{array}{c}\text { \# CV eluted } \\
(\text { lead column })\end{array}$ & $\begin{array}{c}\text { Cs in eluate } \\
(\mu \mathrm{Ci} / \mathrm{mL})\end{array}$ & $\begin{array}{c}\text { Concentration } \\
\text { profile }(\mathrm{C} / \mathrm{Co})\end{array}$ \\
\hline BNF-C320-CsIX-Eluate-Cr4-LCS1 & 2.02 & $7.54 \mathrm{E}-02$ & $4.14 \mathrm{E}-04$ \\
\hline BNF-C320-CsIX-Eluate-Cr4-LCS2 & 3.19 & $1.05 \mathrm{E}+01$ & $5.75 \mathrm{E}-02$ \\
\hline BNF-C320-CsIX-Eluate-Cr4-LCS3 & 5.29 & $1.54 \mathrm{E}+04$ & $8.48 \mathrm{E}+01$ \\
\hline BNF-C320-CsIX-Eluate-Cr4-LCS4 & 8.70 & $2.96 \mathrm{E}+03$ & $1.62 \mathrm{E}+01$ \\
\hline BNF-C320-CsIX-Eluate-Cr4-LCS5 & 11.84 & $5.81 \mathrm{E}+00$ & $3.19 \mathrm{E}-02$ \\
\hline BNF-C320-CsIX-Eluate-Cr4-LCS6 & 14.09 & $2.78 \mathrm{E}+00$ & $1.53 \mathrm{E}-02$ \\
\hline BNF-C320-CsIX-Eluate-Cr4-LCS7 & 16.36 & $1.26 \mathrm{E}+00$ & $6.91 \mathrm{E}-03$ \\
\hline BNF-C320-CsIX-Eluate-Cr4-LCS8 & 18.78 & $3.08 \mathrm{E}-01$ & $1.69 \mathrm{E}-03$ \\
\hline
\end{tabular}

Table 9. Technetium ion exchange column loading profiles for small Envelope C (AN-102) salt solution on SuperLig 639 (Analysis by ICP-MS)

\begin{tabular}{|l|c|c|c|}
\hline Lead column sample ID & $\begin{array}{c}\text { \# CV processed } \\
(\text { lead column })\end{array}$ & $\begin{array}{c}\text { Tc-99 Effluent } \\
(\mu \mathrm{g} / \mathrm{L})\end{array}$ & $\begin{array}{c}\text { Concentration } \\
\text { profile (C/Co })\end{array}$ \\
\hline BNF-C320-TcIX-Feed-1 & na & $4.73 \mathrm{E}+03$ & na \\
\hline BNF-C320-TcIX-Feed-2 & na & $4.63 \mathrm{E}+03$ & na \\
\hline BNF-C320-TcIXEFF-Cr4-LCS1 & 5 & $2.154 \mathrm{E}+03$ & $4.61 \mathrm{E}-01$ \\
\hline BNF-C320-TcIXEFF-Cr4-LCS2 & 10 & $2.884 \mathrm{E}+03$ & $6.17 \mathrm{E}-01$ \\
\hline BNF-C320-TcIXEFF-Cr4-LCS3 & 20 & $2.005 \mathrm{E}+03$ & $4.29 \mathrm{E}-01$ \\
\hline BNF-C320-TcIXEFF-Cr4-LCS4 & 30 & $2.863 \mathrm{E}+03$ & $6.12 \mathrm{E}-01$ \\
\hline BNF-C320-TcIXEFF-Cr4-LCS5 & 40 & $2.901 \mathrm{E}+03$ & $6.21 \mathrm{E}-01$ \\
\hline BNF-C320-TcIXEFF-Cr4-LCS6 & 50 & $3.399 \mathrm{E}+03$ & $7.27 \mathrm{E}-01$ \\
\hline BNF-C320-TcIXEFF-Cr4-LCS7 & 60 & $3.123 \mathrm{E}+03$ & $6.68 \mathrm{E}-01$ \\
\hline Guard column sample ID & & & $6.49 \mathrm{E}-01$ \\
\hline BNF-C320-TcIXEFF-Cr4-1CV-s1 & 13 & $3.036 \mathrm{E}+03$ & $6.66 \mathrm{E}-01$ \\
\hline BNF-C320-TcIXEFF-Cr4-2CV-s2 & 36 & $3.113 \mathrm{E}+03$ & $6.94 \mathrm{E}-01$ \\
\hline BNF-C320-TcIXEFF-Cr4-3CV-s3 & 47 & $3.247 \mathrm{E}+03$ & $2.11 \mathrm{E}-01$ \\
\hline BNF-C320-TcIXNaOH-Cr4-1CVS & 48 & $9.879 \mathrm{E}+02$ & \\
\hline
\end{tabular}


Table 10. Technetium elution profile (lead column)

\begin{tabular}{|l|c|c|c|}
\hline \multicolumn{1}{|c|}{$\begin{array}{c}\text { Sample ID } \\
\text { Lead column }\end{array}$} & $\begin{array}{c}\text { \# CV eluate } \\
\text { (lead column) }\end{array}$ & $\begin{array}{c}\text { Tc-99 eluted } \\
(\mu \mathrm{g} / \mathrm{L})\end{array}$ & $\begin{array}{c}\text { Concentration } \\
\text { profile (C/Co) }\end{array}$ \\
\hline BNF-C320-TcIX-Eluate-Cr4-LTc1 & 1.96 & $4.95 \mathrm{E}+03$ & $1.06 \mathrm{E}+00$ \\
\hline BNF-C320-TcIX-Eluate-Cr4-LTc2 & 4.04 & $1.09 \mathrm{E}+04$ & $2.34 \mathrm{E}+00$ \\
\hline BNF-C320-TcIX-Eluate-Cr4-LTc3 & 5.98 & $1.26 \mathrm{E}+04$ & $2.70 \mathrm{E}+00$ \\
\hline BNF-C320-TcIX-Eluate-Cr4-LTc4 & 8.63 & $2.21 \mathrm{E}+03$ & $4.73 \mathrm{E}-01$ \\
\hline BNF-C320-TcIX-Eluate-Cr4-LTc5 & 9.66 & $6.85 \mathrm{E}+02$ & $1.47 \mathrm{E}-01$ \\
\hline BNF-C320-TcIX-Eluate-Cr4-LTc6 & 11.90 & $1.92 \mathrm{E}+02$ & $4.10 \mathrm{E}-02$ \\
\hline BNF-C320-TcIX-Eluate-Cr4-LTc7 & 14.64 & $9.98 \mathrm{E}+01$ & $2.13 \mathrm{E}-02$ \\
\hline BNF-C320-TcIX-Eluate-Cr4-LTc8 & 18.05 & $1.54 \mathrm{E}+02$ & $3.28 \mathrm{E}-02$ \\
\hline BNF-C320-TcIX-Eluate-Cr4-LTc9 & 21.49 & $4.45 \mathrm{E}+01$ & $9.53 \mathrm{E}-03$ \\
\hline BNF-C320-TcIX-Eluate-Cr4-LTc10 & 24.78 & $1.88 \mathrm{E}+01$ & $4.02 \mathrm{E}-03$ \\
\hline BNF-C320-TcIX-Eluate-Cr4-LTc11 & 28.03 & $1.37 \mathrm{E}+01$ & $2.93 \mathrm{E}-03$ \\
\hline BNF-C320-TcIX-Eluate-Cr4-LTc12 & 31.03 & $1.23 \mathrm{E}+01$ & $2.63 \mathrm{E}-03$ \\
\hline BNF-C320-TcIX-Eluate-Cr4-LTc13 & 34.18 & $1.60 \mathrm{E}+01$ & $3.42 \mathrm{E}-03$ \\
\hline BNF-C320-TcIX-Eluate-Cr4-LTc14 & 36.25 & $7.56 \mathrm{E}+00$ & $1.62 \mathrm{E}-03$ \\
\hline BNF-C320-TcIX-Eluate-Cr4-LTc15 & 37.98 & $7.98 \mathrm{E}+00$ & $1.71 \mathrm{E}-03$ \\
\hline BNF-C320-TcIX-Eluate-Cr4-LTc16 & 39.73 & $8.61 \mathrm{E}+00$ & $1.84 \mathrm{E}-03$ \\
\hline BNF-C320-TcIX-Eluate-Cr4-LTc17 & 41.18 & $1.19 \mathrm{E}+01$ & $2.54 \mathrm{E}-03$ \\
\hline BNF-C320-TcIX-Eluate-Cr4-LTc18 & 41.92 & $7.42 \mathrm{E}+00$ & $1.59 \mathrm{E}-03$ \\
\hline
\end{tabular}


Table 11. Characterization for Envelope $C$ decontaminated product

\begin{tabular}{|c|c|c|c|c|c|c|}
\hline Sample ID & & AN-102-Prod-1 & & AN-102-Prod-2 & & Avg. value \\
\hline $\mathrm{Cs}-137(\mu \mathrm{Ci} / \mathrm{mL})$ & & $1.16 \mathrm{E}-01$ & & $9.55 \mathrm{E}-02$ & & $1.06 \mathrm{E}-01$ \\
\hline $\mathrm{Co}-60(\mu \mathrm{Ci} / \mathrm{mL})$ & & $4.27 \mathrm{E}-02$ & & $4.01 \mathrm{E}-02$ & & $4.14 \mathrm{E}-02$ \\
\hline Eu-154 $(\mu \mathrm{Ci} / \mathrm{mL})$ & & $2.92 \mathrm{E}-02$ & & $2.94 \mathrm{E}-02$ & & $2.93 \mathrm{E}-02$ \\
\hline $\mathrm{Eu}-155(\mu \mathrm{Ci} / \mathrm{mL})$ & & $1.73 \mathrm{E}-02$ & & $1.81 \mathrm{E}-02$ & & $1.77 \mathrm{E}-02$ \\
\hline Tc-99 (mg/L) & & $2.56 \mathrm{E}+00$ & & $2.52 \mathrm{E}+00$ & & $2.54 \mathrm{E}+00$ \\
\hline massTh-232, $\mathrm{mg} / \mathrm{L}$ & & $8.76 \mathrm{E}-01$ & & $1.05 \mathrm{E}+00$ & & $9.65 \mathrm{E}-01$ \\
\hline mass U-233 & $<$ & $7.19 \mathrm{E}-04$ & $<$ & $7.15 \mathrm{E}-04$ & $<$ & $7.17 \mathrm{E}-04$ \\
\hline mass U-235 & $<$ & $7.19 \mathrm{E}-04$ & $<$ & $7.15 \mathrm{E}-04$ & $<$ & 7.17E-04 \\
\hline mass U-236 & $<$ & $7.19 \mathrm{E}-04$ & $<$ & $7.15 \mathrm{E}-04$ & $<$ & $7.17 \mathrm{E}-04$ \\
\hline mass Np-237 & & $8.25 \mathrm{E}-02$ & & $7.79 \mathrm{E}-02$ & & $8.02 \mathrm{E}-02$ \\
\hline mass $\mathrm{Pu} / \mathrm{U}-238$ & & $6.25 \mathrm{E}-01$ & & $6.17 \mathrm{E}-01$ & & $6.21 \mathrm{E}-01$ \\
\hline mass $\mathrm{Pu}-239$ & & $4.31 \mathrm{E}-02$ & & $1.81 E-02$ & & $3.06 \mathrm{E}-02$ \\
\hline mass Pu-240 & $<$ & $7.19 \mathrm{E}-04$ & $<$ & $7.15 \mathrm{E}-04$ & $\leq$ & $7.17 \mathrm{E}-04$ \\
\hline mass Am/Pu-241 & $<$ & $7.19 \mathrm{E}-04$ & $<$ & $7.15 \mathrm{E}-04$ & $<$ & 7.17E-04 \\
\hline mass Am-243 & $<$ & $7.19 \mathrm{E}-04$ & $<$ & $7.15 \mathrm{E}-04$ & $<$ & $7.17 \mathrm{E}-04$ \\
\hline mass Cm-245 & $<$ & $7.19 \mathrm{E}-04$ & $<$ & $7.15 \mathrm{E}-04$ & $<$ & $7.17 \mathrm{E}-04$ \\
\hline $\mathrm{K}(\mathrm{AA}), \mathrm{mg} / \mathrm{L}$ & & $9.09 \mathrm{E}+02$ & & $9.16 \mathrm{E}+02$ & & $9.12 \mathrm{E}+02$ \\
\hline \multicolumn{7}{|l|}{ Carbon (mg/L) } \\
\hline inorganic (TIC) & & $7.06 \mathrm{E}+03$ & & $6.18 \mathrm{E}+03$ & & $6.62 \mathrm{E}+03$ \\
\hline Organic (TOC) & & $2.57 \mathrm{E}+04$ & & $3.17 \mathrm{E}+04$ & & $2.87 E+04$ \\
\hline $\mathrm{OH}^{-}$(Free) & & $8.49 \mathrm{E}-01$ & & $8.10 \mathrm{E}-01$ & & $8.3 \mathrm{E}-01$ \\
\hline \multicolumn{7}{|l|}{$\mathrm{ICP}-\mathrm{ES}(\mathrm{mg} / \mathrm{L})$} \\
\hline $\mathrm{Al}$ & & $6.64 \mathrm{E}+03$ & & $6.49 \mathrm{E}+03$ & & $6.57 \mathrm{E}+03$ \\
\hline$B$ & & $2.30 \mathrm{E}+01$ & & $2.11 \mathrm{E}+01$ & & $2.21 \mathrm{E}+01$ \\
\hline $\mathrm{Ba}$ & $<$ & $1.11 \mathrm{E}+00$ & $<$ & $1.10 \mathrm{E}+00$ & $<$ & $1.11 \mathrm{E}+00$ \\
\hline $\mathrm{Ca}$ & & $2.05 \mathrm{E}+02$ & & $2.00 \mathrm{E}+02$ & & $2.02 \mathrm{E}+02$ \\
\hline $\mathrm{Cd}$ & & $2.59 \mathrm{E}+01$ & & $2.46 \mathrm{E}+01$ & & $2.52 \mathrm{E}+01$ \\
\hline $\mathrm{Co}$ & $<$ & $3.32 \mathrm{E}+00$ & $<$ & $3.31 \mathrm{E}+00$ & $\leq$ & $3.32 \mathrm{E}+00$ \\
\hline $\mathrm{Cr}$ & & $6.92 \mathrm{E}+01$ & & $6.70 \mathrm{E}+01$ & & $6.81 \mathrm{E}+01$ \\
\hline $\mathrm{Cu}$ & & $6.46 \mathrm{E}+00$ & & $5.87 \mathrm{E}+00$ & & $6.17 \mathrm{E}+00$ \\
\hline $\mathrm{Fe}$ & & $3.43 \mathrm{E}+00$ & & $3.61 \mathrm{E}+00$ & & $3.52 \mathrm{E}+00$ \\
\hline $\mathrm{La}$ & $<$ & $4.43 \mathrm{E}+00$ & $<$ & $4.41 \mathrm{E}+00$ & $<$ & $4.42 \mathrm{E}+00$ \\
\hline $\mathrm{Li}$ & $<$ & $1.66 \mathrm{E}+00$ & $<$ & $1.65 \mathrm{E}+00$ & $<$ & $1.66 \mathrm{E}+00$ \\
\hline $\mathrm{Mg}$ & & $2.84 \mathrm{E}+00$ & & $3.17 \mathrm{E}+00$ & & $3.00 \mathrm{E}+00$ \\
\hline $\mathrm{Mn}$ & $<$ & $5.54 \mathrm{E}-01$ & $<$ & $5.52 \mathrm{E}-01$ & $\leq$ & $5.53 \mathrm{E}-01$ \\
\hline Mo & & $3.01 E+01$ & & $2.87 \mathrm{E}+01$ & & $2.94 \mathrm{E}+01$ \\
\hline $\mathrm{Na}$ & & $1.22 \mathrm{E}+05$ & & $1.17 \mathrm{E}+05$ & & $1.20 \mathrm{E}+05$ \\
\hline $\mathrm{Ni}$ & & $1.55 \mathrm{E}+02$ & & $1.47 \mathrm{E}+02$ & & $1.51 \mathrm{E}+02$ \\
\hline $\mathrm{P}$ & & $8.11 \mathrm{E}+02$ & & $8.17 \mathrm{E}+02$ & & $8.14 \mathrm{E}+02$ \\
\hline $\mathrm{Pb}$ & & $5.58 \mathrm{E}+01$ & & $5.77 \mathrm{E}+01$ & & $5.68 \mathrm{E}+01$ \\
\hline $\mathrm{Re}$ & $<$ & $2.83 \mathrm{E}+01$ & $<$ & $2.81 \mathrm{E}+01$ & $<$ & $2.82 \mathrm{E}+01$ \\
\hline $\mathrm{Si}$ & & $6.36 \mathrm{E}+01$ & & $5.62 \mathrm{E}+01$ & & $5.99 \mathrm{E}+01$ \\
\hline $\mathrm{Sn}$ & & $2.45 \mathrm{E}+01$ & & $2.57 \mathrm{E}+01$ & & $2.51 E+01$ \\
\hline $\mathrm{Sr}$ & & $8.42 \mathrm{E}+01$ & & $7.92 \mathrm{E}+01$ & & $8.17 E+01$ \\
\hline $\mathrm{Ti}$ & $<$ & $1.11 \mathrm{E}+00$ & $<$ & $1.10 \mathrm{E}+00$ & $<$ & $1.11 \mathrm{E}+00$ \\
\hline $\mathrm{V}$ & $<$ & $2.22 \mathrm{E}+00$ & $<$ & $2.21 \mathrm{E}+00$ & $<$ & $2.21 E+00$ \\
\hline $\mathrm{Zn}$ & & $.9 .37 \mathrm{E}+00$ & & $9.33 \mathrm{E}+00$ & & $9.35 E+00$ \\
\hline $\mathrm{Zr}$ & & $5.72 \mathrm{E}+00$ & & $3.58 \mathrm{E}+00$ & & $4.65 E+00$ \\
\hline
\end{tabular}


Table 12. Characterization data for cesium eluate product

\begin{tabular}{|c|c|c|c|c|c|c|}
\hline Sample ID & & AN-102-CsELU-1 & & AN-102-CsELU-2 & & Avg. values \\
\hline $\mathrm{Cs}-137(\mu \mathrm{Ci} / \mathrm{mL})$ & & $5.12 \mathrm{E}+02$ & & $5.10 \mathrm{E}+02$ & & $5.11 \mathrm{E}+02$ \\
\hline Tc-99 (mg/L) & & $6.21 \mathrm{E}-02$ & & $5.08 \mathrm{E}-02$ & & $5.64 \mathrm{E}-02$ \\
\hline total alpha (dpm/ml) & & $5.04 \mathrm{E}+07$ & & $5.10 \mathrm{E}+07$ & & $5.07 \mathrm{E}+07$ \\
\hline $\mathrm{K}(\mathrm{AA}), \mathrm{mg} / \mathrm{L}$ & & $8.91 \mathrm{E}+1$ & & $7.10 \mathrm{E}+1$ & & $8.01 \mathrm{E}+1$ \\
\hline \multicolumn{7}{|l|}{ Carbon (mg/L) } \\
\hline inorganic (TIC) & $<$ & $2.16 \mathrm{E}+1$ & $<$ & $2.13 \mathrm{E}+1$ & $<$ & $2.15 \mathrm{E}+1$ \\
\hline Organic (TOC) & & $6.94 \mathrm{E}+2$ & & $2.45 \mathrm{E}+2$ & & $4.70 \mathrm{E}+2$ \\
\hline \multicolumn{7}{|l|}{$\operatorname{IC}(\mathrm{mg} / \mathrm{L})$} \\
\hline $\mathrm{NO}_{3}^{-}$ & & $2.30 \mathrm{E}+04$ & & $2.18 \mathrm{E}+04$ & & $2.24 \mathrm{E}+04$ \\
\hline $\mathrm{NO}_{2}^{-}$ & $<$ & $2.16 \mathrm{E}+03$ & $<$ & $2.13 E+03$ & $<$ & $2.15 \mathrm{E}+03$ \\
\hline $\mathrm{PO} 4$ & $<$ & $2.16 \mathrm{E}+03$ & $<$ & $2.13 E+03$ & $<$ & $2.15 \mathrm{E}+03$ \\
\hline $\mathrm{SO} 4$ & $<$ & $1.08 \mathrm{E}+03$ & $<$ & $1.07 \mathrm{E}+03$ & $<$ & $1.07 \mathrm{E}+03$ \\
\hline Oxalate & $<$ & $2.16 \mathrm{E}+03$ & $<$ & $2.13 E+03$ & $<$ & $2.15 \mathrm{E}+03$ \\
\hline $\mathrm{Cl}$ - by IC & $<$ & $4.32 \mathrm{E}+02$ & $<$ & $4.27 \mathrm{E}+02$ & $<$ & $4.30 \mathrm{E}+02$ \\
\hline $\mathrm{F}$ - by IC & $<$ & $4.32 E+02$ & $<$ & $4.27 \mathrm{E}+02$ & $<$ & $4.30 \mathrm{E}+02$ \\
\hline $\mathrm{Cl}^{-}$(ISE) & & $5.87 \mathrm{E}+03$ & & na & & $5.87 \mathrm{E}+03$ \\
\hline $\mathrm{F}^{\prime}$ (ISE) & $<$ & $2.16 \mathrm{E}+01$ & & na & $<$ & $2.16 \mathrm{E}+01$ \\
\hline \multicolumn{7}{|l|}{ Chem-check } \\
\hline $\mathrm{U}(\mathrm{mg} / \mathrm{L})$ & & $1.77 E+01$ & & $1.58 \mathrm{E}+01$ & & $1.68 \mathrm{E}+01$ \\
\hline \multicolumn{7}{|l|}{ ICP-ES $(\mathrm{mg} / \mathrm{L})$} \\
\hline $\mathrm{Al}$ & & $2.50 \mathrm{E}+02$ & & $2.85 E+02$ & & $2.68 \mathrm{E}+02$ \\
\hline $\mathrm{B}$ & & $2.03 E+02$ & & $2.43 \mathrm{E}+02$ & & $2.23 E+02$ \\
\hline $\mathrm{Ba}$ & & $5.62 \mathrm{E}-01$ & & $5.42 \mathrm{E}-01$ & & $5.52 \mathrm{E}-01$ \\
\hline $\mathrm{Ca}$ & & $6.21 E+01$ & & $6.94 \mathrm{E}+01$ & & $6.57 \mathrm{E}+01$ \\
\hline $\mathrm{Cd}$ & & $1.23 \mathrm{E}+00$ & & $8.23 \mathrm{E}-01$ & & $1.03 E+00$ \\
\hline Co & $<$ & $1.30 \mathrm{E}+00$ & $<$ & $1.30 \mathrm{E}+00$ & $<$ & $1.30 \mathrm{E}+00$ \\
\hline $\mathrm{Cr}$ & & $9.80 \mathrm{E}+00$ & & $8.82 \mathrm{E}+00$ & & $9.31 \mathrm{E}+00$ \\
\hline $\mathrm{Cu}$ & & $2.98 \mathrm{E}+01$ & & $2.94 \mathrm{E}+01$ & & $2.96 \mathrm{E}+01$ \\
\hline $\mathrm{Fe}$ & & $7.27 \mathrm{E}+00$ & & $5.96 \mathrm{E}+00$ & & $6.61 \mathrm{E}+00$ \\
\hline $\mathrm{La}$ & $<$ & $1.73 E+00$ & $<$ & $1.73 E+00$ & $<$ & $1.73 \mathrm{E}+00$ \\
\hline $\mathrm{Li}$ & $<$ & $6.49 \mathrm{E}-01$ & $<$ & $6.50 \mathrm{E}-01$ & $<$ & $6.49 \mathrm{E}-01$ \\
\hline $\mathrm{Mg}$ & & $8.48 \mathrm{E}+00$ & & $9.42 \mathrm{E}+00$ & & $8.95 \mathrm{E}+00$ \\
\hline $\mathrm{Mn}$ & & $6.70 \mathrm{E}-01$ & & $5.85 \mathrm{E}-01$ & & $6.28 \mathrm{E}-01$ \\
\hline Mo & $<$ & $4.32 \mathrm{E}-01$ & & $4.77 \mathrm{E}-01$ & $<$ & $4.55 \mathrm{E}-01$ \\
\hline $\mathrm{Na}$ & & $1.50 \mathrm{E}+03$ & & $1.47 \mathrm{E}+03$ & & $1.48 \mathrm{E}+03$ \\
\hline $\mathrm{Ni}$ & & $4.50 \mathrm{E}+01$ & & $4.58 \mathrm{E}+01$ & & $4.54 \mathrm{E}+01$ \\
\hline $\mathrm{P}$ & $<$ & $9.51 \mathrm{E}+00$ & $<$ & $9.53 E+00$ & $<$ & $9.52 \mathrm{E}+00$ \\
\hline $\mathrm{Pb}$ & $<$ & $9.30 \mathrm{E}+00$ & $<$ & $9.32 E+00$ & $<$ & $9.31 E+00$ \\
\hline $\mathrm{Re}$ & $<$ & $1.10 \mathrm{E}+01$ & $<$ & $1.10 \mathrm{E}+01$ & $<$ & $1.10 \mathrm{E}+01$ \\
\hline $\mathrm{Si}$ & & $9.46 \mathrm{E}+01$ & & $1.02 \mathrm{E}+02$ & & $9.85 \mathrm{E}+01$ \\
\hline $\mathrm{Sn}$ & $<$ & $4.32 \mathrm{E}+00$ & $<$ & $4.33 E+00$ & $<$ & $4.33 \mathrm{E}+00$ \\
\hline $\mathrm{Sr}$ & & $1.04 \mathrm{E}+00$ & & $1.10 \mathrm{E}+00$ & & $1.07 \mathrm{E}+00$ \\
\hline $\mathrm{Ti}$ & & $4.97 \mathrm{E}-01$ & $<$ & $4.33 \mathrm{E}-01$ & $<$ & $4.65 \mathrm{E}-01$ \\
\hline $\mathrm{V}$ & $<$ & $8.65 \mathrm{E}-01$ & $<$ & $8.67 \mathrm{E}-01$ & $<$ & $8.66 \mathrm{E}-01$ \\
\hline $\mathrm{Zn}$ & & $3.61 \mathrm{E}+00$ & & $3.79 \mathrm{E}+00$ & & $3.70 \mathrm{E}+00$ \\
\hline $\mathrm{Zr}$ & $<$ & $1.08 \mathrm{E}+00$ & $<$ & $1.08 \mathrm{E}+00$ & $<$ & $1.08 \mathrm{E}+00$ \\
\hline
\end{tabular}


Table 13. Characterization Data for Technetium Eluate Product

\begin{tabular}{|c|c|c|c|c|c|c|}
\hline Sample ID & & A-103-TcELU-1 & & A-103-TcELU-2 & & Avg. values \\
\hline $\mathrm{Cs}-137(\mu \mathrm{Ci} / \mathrm{mL})$ & & $1.08 \mathrm{E}-02$ & & $1.88 \mathrm{E}-02$ & & $1.48 \mathrm{E}-02$ \\
\hline Tc-99 (mg/L) & & $1.95 \mathrm{E}+00$ & & $1.94 \mathrm{E}+00$ & & $1.95 \mathrm{E}+00$ \\
\hline total alpha (dpm/ml) & & $4.55 E+03$ & & $4.30 \mathrm{E}+03$ & & $4.43 E+03$ \\
\hline $\mathrm{K}(\mathrm{AA}), \mathrm{mg} / \mathrm{L}$ & & $1.01 \mathrm{E}+1$ & & $8.20 \mathrm{E}+0$ & & $9.14 \mathrm{E}+00$ \\
\hline inorganic (TIC) & $<$ & $2.23 E+1$ & $<$ & $6.98 \mathrm{E}+1$ & $<$ & $4.60 \mathrm{E}+1$ \\
\hline Organic (TOC) & & $3.30 \mathrm{E}+2$ & & $1.12 \mathrm{E}+2$ & & $2.21 E+02$ \\
\hline \multicolumn{7}{|l|}{ IC $(\mathrm{mg} / \mathrm{L})$} \\
\hline $\mathrm{NO}_{3}{ }^{-}$ & & $2.23 E+03$ & $<$ & $2.24 \mathrm{E}+03$ & & $2.24 E+03$ \\
\hline $\mathrm{NO}_{2}^{-}$ & & $2.23 E+03$ & & $2.24 \mathrm{E}+03$ & & $2.24 E+03$ \\
\hline $\mathrm{PO}_{4}$ & $<1$ & $2.23 E+03$ & $<$ & $2.24 E+03$ & $<$ & $2.24 \mathrm{E}+03$ \\
\hline $\mathrm{SO}_{4}$ & $<$ & $1.12 \mathrm{E}+03$ & $<$ & $1.12 \mathrm{E}+03$ & $<$ & $1.12 \mathrm{E}+03$ \\
\hline Oxalate & $<$ & $2.23 E+03$ & $<$ & $2.24 \mathrm{E}+03$ & $<$ & $2.24 \mathrm{E}+03$ \\
\hline $\mathrm{Cl}^{-}$ & & $6.34 \mathrm{E}+03$ & & $5.97 \mathrm{E}+03$ & & $6.15 \mathrm{E}+03$ \\
\hline $\mathrm{F}$ & $<$ & $2.23 \mathrm{E}+01$ & $<$ & $2.24 \mathrm{E}+01$ & $<$ & $2.24 \mathrm{E}+01$ \\
\hline $\mathrm{Cl}$ (ISE) & & $6.34 \mathrm{E}+03$ & & $5.97 \mathrm{E}+03$ & & $6.15 E+03$ \\
\hline $\mathrm{F}$ (ISE) & $<$ & $2.23 \mathrm{E}+01$ & $<1$ & $2.24 \mathrm{E}+01$ & $<$ & $2.24 \mathrm{E}+01$ \\
\hline $\mathrm{U}(\mathrm{mg} / \mathrm{L})$ & $<$ & $2.23 \mathrm{E}-01$ & $<$ & $2.24 \mathrm{E}-01$ & $<$ & $2.24 \mathrm{E}-01$ \\
\hline \multicolumn{7}{|l|}{ ICP-ES (mg/L) } \\
\hline $\mathrm{Al}$ & & $2.11 \mathrm{E}+01$ & & $2.22 \mathrm{E}+01$ & & $2.16 \mathrm{E}+01$ \\
\hline $\mathrm{B}$ & $<$ & $2.68 \mathrm{E}+00$ & $<$ & $2.69 \mathrm{E}+00$ & $<$ & $2.68 \mathrm{E}+00$ \\
\hline $\mathrm{Ba}$ & & $1.05 \mathrm{E}+00$ & & $9.86 \mathrm{E}-01$ & & $1.02 \mathrm{E}+00$ \\
\hline $\mathrm{Ca}$ & & $9.28 \mathrm{E}+00$ & & $7.93 \mathrm{E}+00$ & & $8.60 \mathrm{E}+00$ \\
\hline $\mathrm{Cd}$ & & $1.07 \mathrm{E}+00$ & & $8.74 \mathrm{E}-01$ & & $9.72 \mathrm{E}-01$ \\
\hline $\mathrm{Co}$ & & $2.54 \mathrm{E}+00$ & & $2.22 \mathrm{E}+00$ & & $2.38 \mathrm{E}+00$ \\
\hline $\mathrm{Cr}$ & & $2.34 \mathrm{E}+00$ & & $1.70 \mathrm{E}+00$ & & $2.02 \mathrm{E}+00$ \\
\hline $\mathrm{Cu}$ & & $1.76 \mathrm{E}+00$ & & $1.59 \mathrm{E}+00$ & & $1.68 \mathrm{E}+00$ \\
\hline $\mathrm{Fe}$ & & $2.21 \mathrm{E}+00$ & & $2.06 \mathrm{E}+00$ & & $2.13 E+00$ \\
\hline $\mathrm{La}$ & & $9.79 \mathrm{E}+00$ & & $8.71 E+00$ & & $9.25 \mathrm{E}+00$ \\
\hline $\mathrm{Li}$ & & $1.45 \mathrm{E}+00$ & & $1.39 \mathrm{E}+00$ & & $1.42 \mathrm{E}+00$ \\
\hline $\mathrm{Mg}$ & & $1.43 \mathrm{E}+00$ & & $1.30 \mathrm{E}+00$ & & $1.36 \mathrm{E}+00$ \\
\hline $\mathrm{Mn}$ & & $3.57 \mathrm{E}-01$ & & $2.91 \mathrm{E}-01$ & & $3.24 \mathrm{E}-01$ \\
\hline Mo & & $9.37 \mathrm{E}-01$ & & $5.60 \mathrm{E}-01$ & & $7.48 \mathrm{E}-01$ \\
\hline $\mathrm{Na}$ & & $3.16 \mathrm{E}+02$ & & $4.18 \mathrm{E}+02$ & & $3.67 \mathrm{E}+02$ \\
\hline $\mathrm{Ni}$ & & $2.68 \mathrm{E}+00$ & & $3.00 \mathrm{E}+00$ & & $2.84 \mathrm{E}+00$ \\
\hline $\mathrm{P}$ & $<$ & $9.81 \mathrm{E}+00$ & $<$ & $9.86 \mathrm{E}+00$ & $<$ & $9.83 E+00$ \\
\hline $\mathrm{Pb}$ & & $1.07 \mathrm{E}+01$ & & $1.04 \mathrm{E}+01$ & & $1.06 \mathrm{E}+01$ \\
\hline $\mathrm{Re}$ & $<$ & $1.14 \mathrm{E}+01$ & $<$ & $1.14 \mathrm{E}+01$ & $<$ & $1.14 \mathrm{E}+01$ \\
\hline $\mathrm{Si}$ & & $1.47 \mathrm{E}+01$ & & $1.42 \mathrm{E}+01$ & & $1.44 \mathrm{E}+01$ \\
\hline Sn & $<$ & $4.46 \mathrm{E}+00$ & $<$ & $4.48 \mathrm{E}+00$ & $<$ & $4.47 \mathrm{E}+00$ \\
\hline $\mathrm{Sr}$ & & $5.13 \mathrm{E}-01$ & & $4.48 \mathrm{E}-01$ & & $4.80 \mathrm{E}-01$ \\
\hline $\mathrm{Ti}$ & & $1.72 \mathrm{E}+00$ & & $1.55 \mathrm{E}+00$ & & $1.63 \mathrm{E}+00$ \\
\hline $\mathrm{V}$ & & $2.88 \mathrm{E}+00$ & & $2.67 \mathrm{E}+00$ & & $2.77 \mathrm{E}+00$ \\
\hline $\mathrm{Zn}$ & & $1.38 \mathrm{E}+00$ & & $1.12 \mathrm{E}+00$ & & $1.25 \mathrm{E}+00$ \\
\hline $\mathrm{Zr}$ & & $2.81 \mathrm{E}+00$ & & $2.76 \mathrm{E}+00$ & & $2.78 \mathrm{E}+00$ \\
\hline
\end{tabular}


Table 14. Resin digestion and analyses results

\begin{tabular}{|c|c|c|c|c|c|c|c|c|c|}
\hline Sample ID & & SuperLig 639 & & SuperLig 639 & & SuperLig 644 & & SuperLig 644 & TCLP limit \\
\hline $\mathrm{Cs}-137(\mu \mathrm{Ci} / \mathrm{g})$ & & $2.92 \mathrm{E}-02$ & & $4.41 \mathrm{E}-02$ & & $6.88 \mathrm{E}+00$ & & $7.85 \mathrm{E}+00$ & $(w t \%)$ \\
\hline Tc-99 $(\mu \mathrm{g} / \mathrm{g})$ & & 3.58 & & 3.26 & & 3.97 & & 5.02 & \\
\hline Mass $230(\mathrm{ug} / \mathrm{g})$ & $<$ & 0.44 & $<$ & 0.43 & $<$ & 0.47 & $<$ & 0.44 & \\
\hline 231 & $<$ & 0.44 & $<$ & 0.43 & $<$ & 0.47 & $<$ & 0.44 & \\
\hline 232 & & 9.41 & & 7.68 & $<$ & 0.47 & $<$ & 0.44 & \\
\hline 233 & $<$ & 0.44 & $<$ & 0.43 & $<$ & 0.47 & $<$ & 0.44 & \\
\hline 234 & $<$ & 0.44 & $<$ & 0.43 & $<$ & 0.47 & $<$ & 0.44 & \\
\hline 235 & $<$ & 0.44 & $<$ & 0.43 & $<$ & 0.47 & $<$ & 0.44 & \\
\hline 236 & $<$ & 0.44 & $<$ & 0.43 & $<$ & 0.47 & $<$ & 0.44 & \\
\hline 237 & $<$ & 0.44 & $<$ & 0.43 & $<$ & 0.47 & $<$ & 0.44 & \\
\hline 238 & $<$ & 0.44 & $<$ & 0.43 & 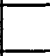 & 7.73 & & 10.15 & \\
\hline 239 & $<$ & 0.44 & $<$ & 0.43 & $<$ & 0.47 & $<$ & 0.44 & \\
\hline 240 & $<$ & 0.44 & $<$ & 0.43 & $<$ & 0.47 & $<$ & 0.44 & \\
\hline 241 & $<$ & 0.44 & $<$ & 0.43 & $<$ & 0.47 & $<$ & 0.44 & \\
\hline 242 & $<$ & 0.44 & $<$ & 0.43 & $<$ & 0.47 & $<$ & 0.44 & \\
\hline \multicolumn{10}{|l|}{$\begin{array}{l}\text { AA analysis, wt. } \\
\%\end{array}$} \\
\hline $\mathrm{K}$ & & $2.40 \mathrm{E}-03$ & & $2.50 \mathrm{E}-03$ & & 2.70E-03 & & $3.31 \mathrm{E}-03$ & \\
\hline As & & $9.07 \mathrm{E}-05$ & & $1.03 \mathrm{E}-04$ & & $1.13 \mathrm{E}-04$ & & $1.13 E-04$ & $1.00 \mathrm{E}-02$ \\
\hline $\mathrm{Se}$ & & $3.46 \mathrm{E}-05$ & & $4.18 \mathrm{E}-05$ & & $4.52 \mathrm{E}-05$ & & $4.95 E-05$ & $2.00 \mathrm{E}-03$ \\
\hline $\mathrm{Hg}$ & $<$ & $1.00 \mathrm{E}-04$ & $<$ & $1.00 \mathrm{E}-04$ & $<$ & $1.00 \mathrm{E}-04$ & $<$ & $1.00 \mathrm{E}-04$ & $4.00 \mathrm{E}-04$ \\
\hline \multicolumn{10}{|l|}{ Chem Check } \\
\hline $\mathrm{U}(\mu \mathrm{g} / \mathrm{g})$ & $<$ & $9.10 \mathrm{E}+03$ & $<$ & $8.99 E+03$ & $<$ & $9.72 \mathrm{E}+03$ & $<$ & $9.25 \mathrm{E}+03$ & \\
\hline \multicolumn{10}{|l|}{ ICP-ES, wt. $\%$} \\
\hline $\mathrm{Ag}$ & $<$ & $5.46 \mathrm{E}-06$ & $<$ & $5.46 \mathrm{E}-06$ & $<$ & 5.83E-06 & $<$ & $5.55 \mathrm{E}-06$ & $1.00 \mathrm{E}-02$ \\
\hline $\overrightarrow{\mathrm{Al}}$ & $<$ & $2.46 \mathrm{E}-05$ & $<$ & $2.46 \mathrm{E}-05$ & $<$ & $2.62 \mathrm{E}-05$ & $<$ & $2.50 \mathrm{E}-05$ & \\
\hline$B$ & $<$ & $1.09 E-05$ & $<$ & $1.09 \mathrm{E}-05$ & $<$ & $1.17 \mathrm{E}-05$ & $<$ & $1.11 \mathrm{E}-05$ & \\
\hline $\mathrm{Ba}$ & $<$ & $1.82 E-06$ & $<$ & $1.82 \mathrm{E}-06$ & $<$ & $1.94 \mathrm{E}-06$ & $<$ & $1.85 \mathrm{E}-06$ & $2.00 \mathrm{E}-01$ \\
\hline $\mathrm{Ca}$ & & $2.95 E-04$ & & $2.95 \mathrm{E}-04$ & & $3.22 \mathrm{E}-04$ & & 4.17E-04 & \\
\hline Cd & $<$ & 1.82E-06 & $<$ & $1.82 \mathrm{E}-06$ & $<$ & $1.94 \mathrm{E}-06$ & $<$ & $1.85 \mathrm{E}-06$ & $2.00 \mathrm{E}-03$ \\
\hline Co & $<$ & $5.46 \mathrm{E}-06$ & $<$ & $5.46 \mathrm{E}-06$ & $<$ & $5.83 \mathrm{E}-06$ & $<$ & $5.55 \mathrm{E}-06$ & \\
\hline $\mathrm{Cr}$ & $<$ & 4.55E-06 & $<$ & $4.55 \mathrm{E}-06$ & & $1.47 \mathrm{E}-04$ & & $1.98 \mathrm{E}-04$ & $1.00 \mathrm{E}-02$ \\
\hline $\mathrm{Cu}$ & $<$ & $2.73 \mathrm{E}-06$ & $<$ & $2.73 \mathrm{E}-06$ & & $5.22 \mathrm{E}-05$ & & 7.44E-05 & \\
\hline $\mathrm{Fe}$ & & $8.88 \mathrm{E}-06$ & & $8.88 \mathrm{E}-06$ & & $4.34 \mathrm{E}-06$ & & 8.93E-06 & \\
\hline La & $<$ & $7.28 \mathrm{E}-06$ & $<$ & $7.28 \mathrm{E}-06$ & $<$ & $7.78 \mathrm{E}-06$ & $<$ & $7.40 \mathrm{E}-06$ & \\
\hline $\mathrm{Li}$ & $<$ & $2.73 \mathrm{E}-06$ & $<$ & 2.73E-06 & $<$ & $2.92 \mathrm{E}-06$ & $<$ & $2.77 \mathrm{E}-06$ & \\
\hline $\mathrm{Mg}$ & & 5.51E-05 & & $5.51 \mathrm{E}-05$ & & $5.49 \mathrm{E}-05$ & & $7.28 \mathrm{E}-05$ & \\
\hline $\mathrm{Mn}$ & $<$ & $9.10 \mathrm{E}-07$ & $<$ & $9.10 \mathrm{E}-07$ & $<$ & $9.72 \mathrm{E}-07$ & $<$ & $9.25 \mathrm{E}-07$ & \\
\hline Mo & $<$ & $1.82 \mathrm{E}-06$ & $<$ & $1.82 \mathrm{E}-06$ & $<$ & $1.94 \mathrm{E}-06$ & $<$ & $1.85 \mathrm{E}-06$ & \\
\hline $\mathrm{Na}$ & & 1.29E-03 & & $1.29 \mathrm{E}-03$ & & $8.86 \mathrm{E}-03$ & & $1.11 \mathrm{E}-02$ & \\
\hline $\mathrm{Ni}$ & $<$ & $9.10 \mathrm{E}-06$ & $<$ & $9.10 \mathrm{E}-06$ & $<$ & $9.72 \mathrm{E}-06$ & $<$ & $9.25 \mathrm{E}-06$ & \\
\hline $\mathrm{P}$ & $<$ & $4.00 \mathrm{E}-05$ & $<$ & $4.00 \mathrm{E}-05$ & $<$ & $4.28 \mathrm{E}-05$ & $<$ & $4.07 \mathrm{E}-05$ & \\
\hline $\mathrm{Pb}$ & $<$ & 3.91E-05 & $<$ & $3.91 \mathrm{E}-05$ & $<$ & $4.18 \mathrm{E}-05$ & $<$ & $3.98 \mathrm{E}-05$ & \\
\hline $\mathrm{Si}$ & $<$ & $2.46 \mathrm{E}-05$ & $<$ & $2.46 \mathrm{E}-05$ & $<$ & $2.62 \mathrm{E}-05$ & $<$ & $2.50 \mathrm{E}-05$ & \\
\hline Sn & $<$ & $1.82 E-05$ & $<$ & $1.82 \mathrm{E}-05$ & $<$ & $1.94 \mathrm{E}-05$ & $<$ & $1.85 \mathrm{E}-05$ & \\
\hline $\mathrm{Sr}$ & $<$ & 1.82E-06 & $<$ & $1.82 \mathrm{E}-06$ & $<$ & $1.94 \mathrm{E}-06$ & $<$ & $1.85 \mathrm{E}-06$ & \\
\hline $\mathrm{Ti}$ & $<$ & 1.82E-06 & $<$ & $1.82 \mathrm{E}-06$ & $<$ & $1.94 \mathrm{E}-06$ & $<$ & $1.85 \mathrm{E}-06$ & \\
\hline $\mathrm{V}$ & $<$ & $3.64 \mathrm{E}-06$ & $<$ & $3.64 \mathrm{E}-06$ & $<$ & $3.89 \mathrm{E}-06$ & $<$ & $3.70 \mathrm{E}-06$ & \\
\hline $\mathrm{Zn}$ & & $6.59 E-06$ & & $6.59 \mathrm{E}-06$ & & $8.40 \mathrm{E}-06$ & & $1.10 \mathrm{E}-05$ & \\
\hline $\mathrm{Zr}$ & $<$ & $4.55 E-06$ & $<$ & $4.55 \mathrm{E}-06$ & $<$ & $4.86 \mathrm{E}-06$ & $<$ & $4.62 \mathrm{E}-06$ & \\
\hline
\end{tabular}




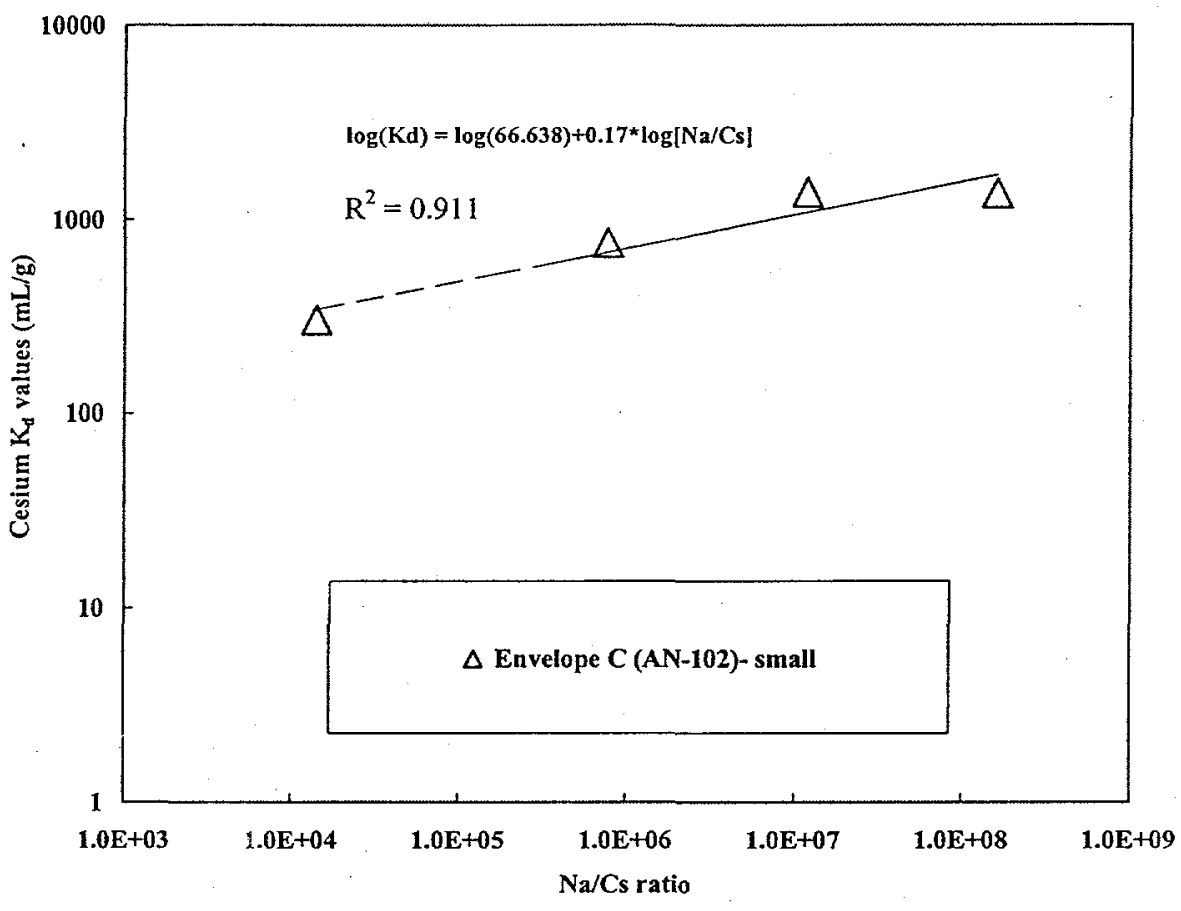

Figure 1. Log-Log plot of cesium equilibrium distribution coefficient

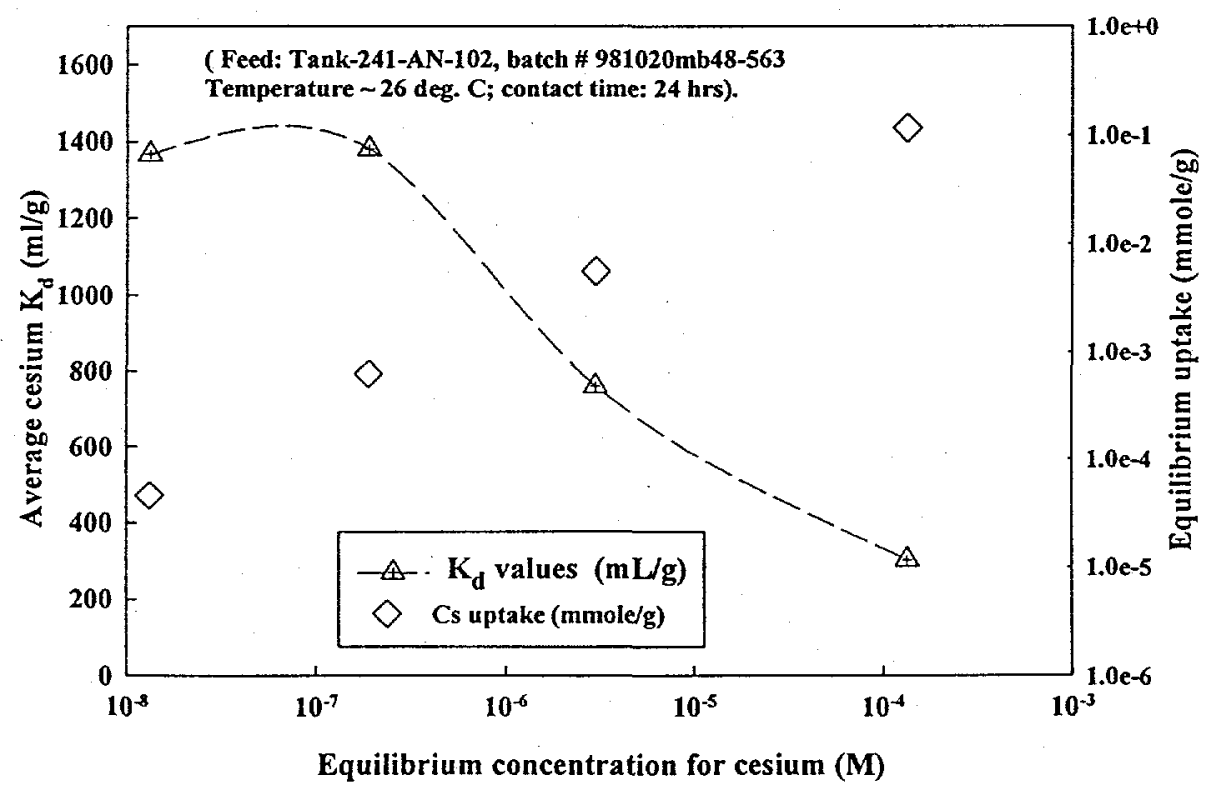

Figure 2 . Batch distribution coefficients for cesium on SuperLig 644 


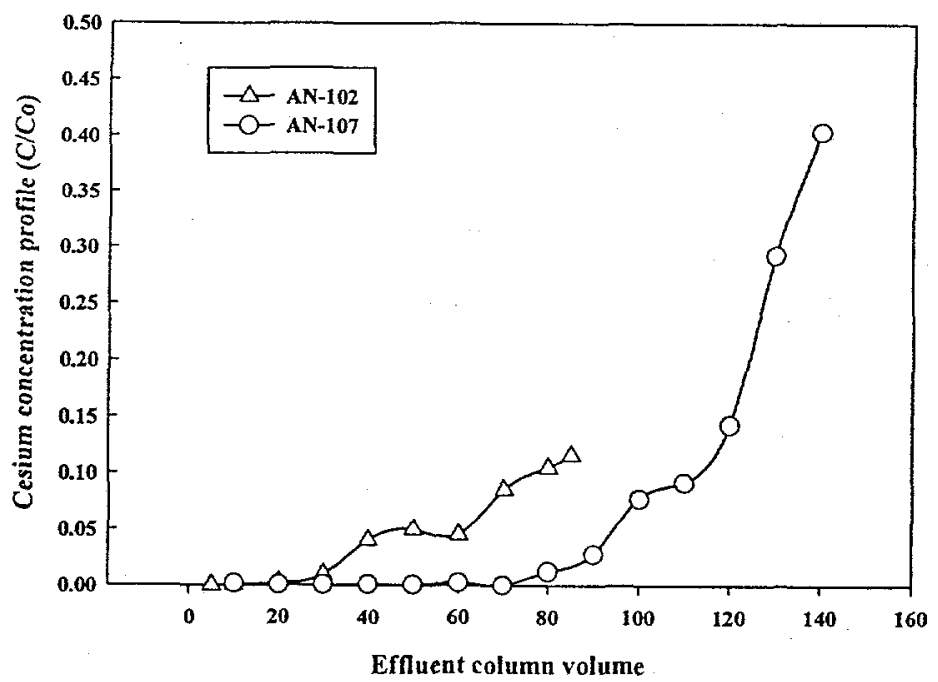

Figure 3. The loading breakthrough profile for Cs-137 on SuperLig 644 resin

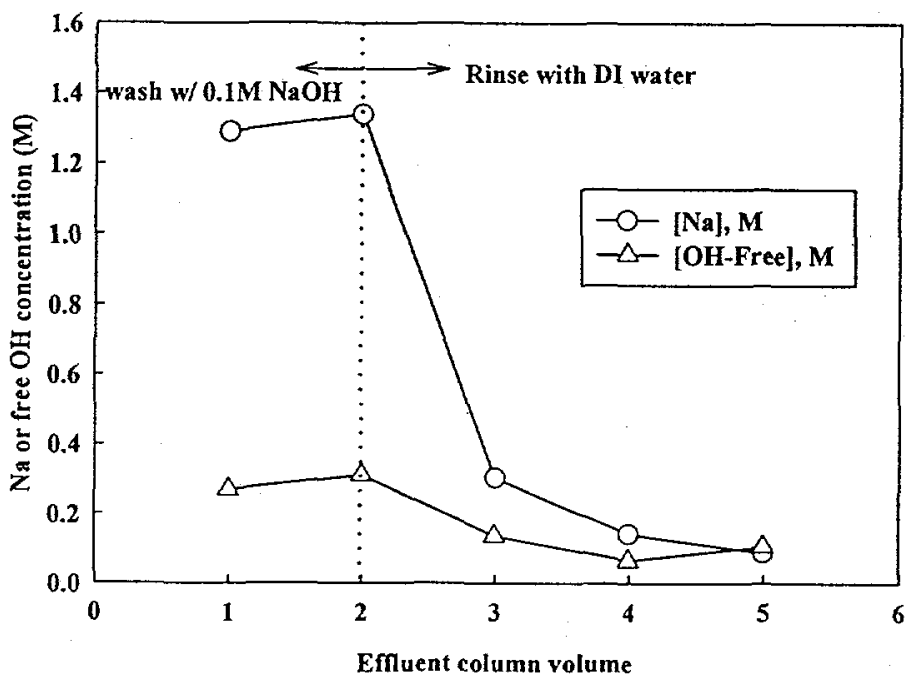

Figure 4. The $\mathrm{Na}$ and free $\mathrm{OH}$ concentrations in feed displacement and rinse solutions post $\mathrm{Cs}$ ion exchange column loading 


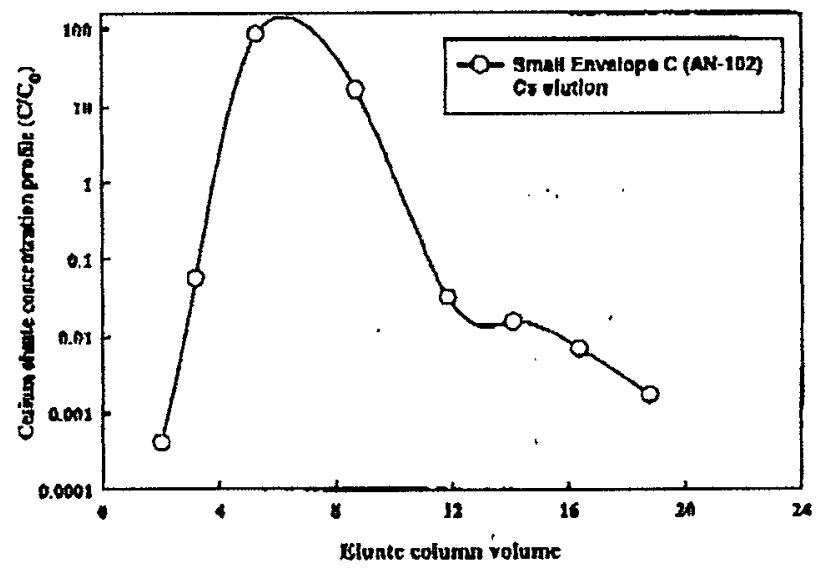

Figure 5. The elwale concenoraion profic for Ca-137 on Superuf G4t renio

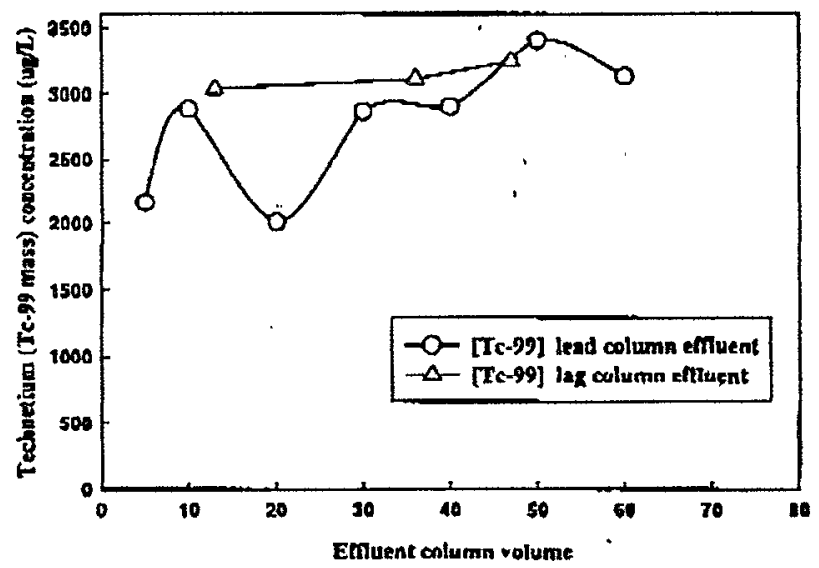

Figure 6. The londing breakthrough profile for TC-99 on SuperLig 639 resil 


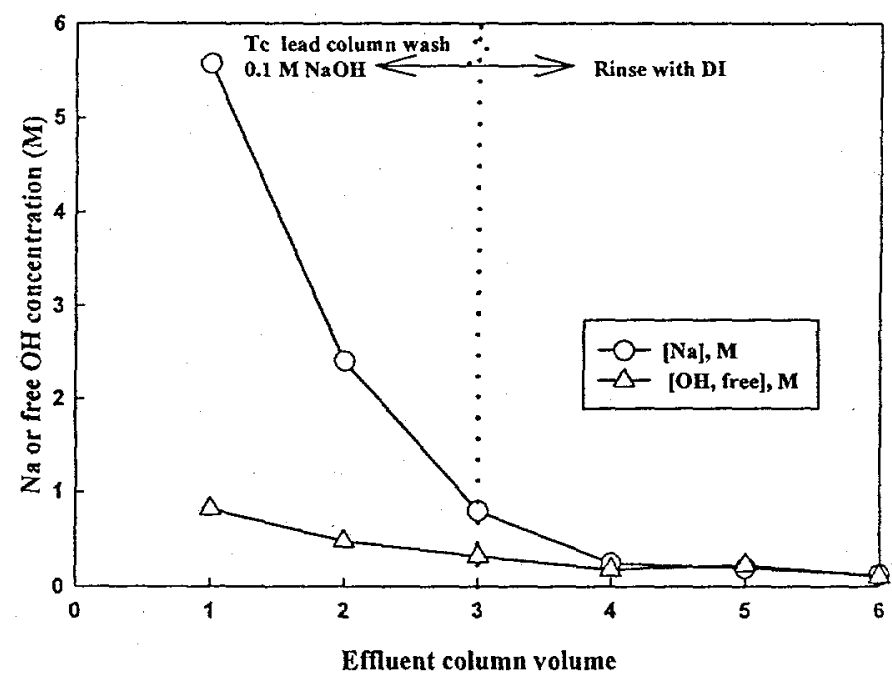

Figure 7. The feed displacement and rinse concentrations of $\mathrm{Na}$ and free $\mathrm{OH}$

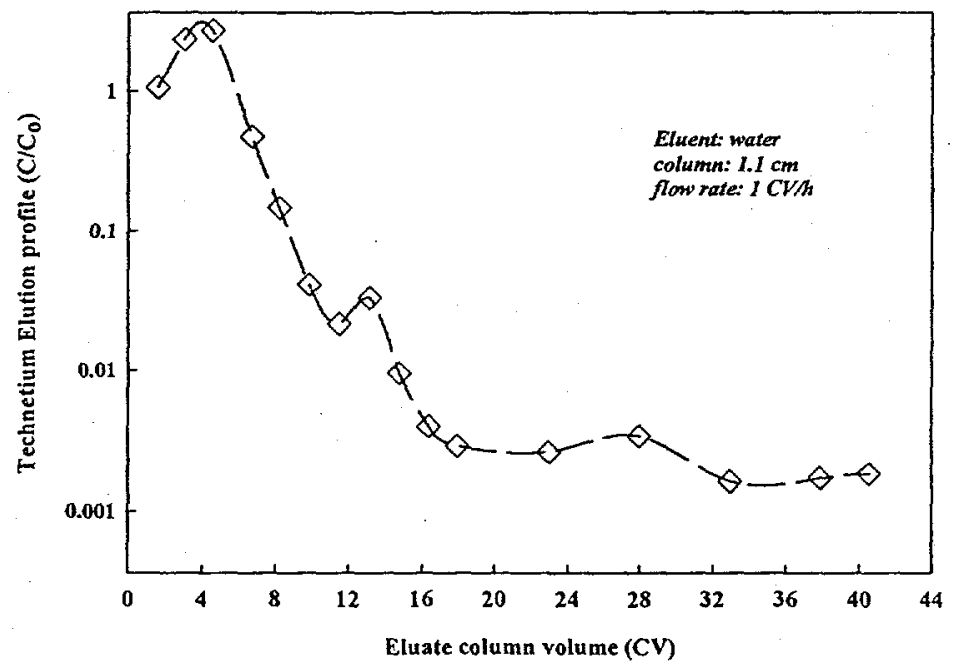

Figure 8. Technetium elution curve for AN-102 from Superlig 639 resin bed 